\title{
CAMA
}

Centre for Applied Macroeconomic Analysis

\section{Do Transparency Initiatives Work? Assessing the Impact of the Special Data Dissemination Standard (SDDS) on Data Transparency}

\section{CAMA Working Paper 24/2015 July 2015}

\author{
Arusha Cooray \\ Business School, University of Nottingham Malaysia Campus and \\ Centre for Applied Macroeconomic Analysis (CAMA), ANU \\ Krishna Chaitanya Vadlamannati \\ Norwegian University of Science and Technology
}

\begin{abstract}
The Special Data Dissemination Standard (SDDS) initiative was launched by the International Monetary Fund (IMF) in 1996, to enhance the availability of timely and comprehensive macroeconomic and financial statistics based on best dissemination practices, facilitating the pursuit of sound macroeconomic policies. By joining this initiative, governments signal their commitment to disclose policy-relevant data. Has the SDDS initiative served its purpose? We provide first quantitative evidence on the effects of the SDDS data transparency initiative. We use Hollyer, Rosendorff and Vreeland's (2014) Data Transparency Index which gauges governments' ability to collect and disseminate aggregate economic data using a Bayesian item response algorithm model, which treats transparency as a latent predictor of the reporting (absence) on 240 variables collected from the World Bank's World Development Indicators. Using panel data on 120 countries during the 1996-2011 period, we find that countries complying with the SDDS initiative are associated with an increase in data transparency index after controlling for self-section bias. Our results are robust to controlling for endogeneity using instrumental variables, alternative sample, and estimation methods.
\end{abstract}




\section{Keywords}

Data transparency, SDDS initiative, IMF.

JEL Classification

Address for correspondence:

(E) cama.admin@anu.edu.au

The Centre for Applied Macroeconomic Analysis in the Crawford School of Public Policy has been established to build strong links between professional macroeconomists. It provides a forum for quality macroeconomic research and discussion of policy issues between academia, government and the private sector.

The Crawford School of Public Policy is the Australian National University's public policy school, serving and influencing Australia, Asia and the Pacific through advanced policy research, graduate and executive education, and policy impact. 


\title{
Do Transparency Initiatives Work? Assessing the Impact of the Special Data Dissemination Standard (SDDS) on Data Transparency
}

\author{
Arusha Cooray \\ Business School \\ University of Nottingham Malaysia Campus \\ Centre for Applied Macroeconomics, Australian National University \\ Arusha.Cooray@nottingham.edu.my \\ Krishna Chaitanya Vadlamannati \\ Norwegian University of Science and Technology \\ Trondheim, Norway \\ krishna.c.vadlamannati@svt.ntnu.no
}

\begin{abstract}
The Special Data Dissemination Standard (SDDS) initiative was launched by the International Monetary Fund (IMF) in 1996, to enhance the availability of timely and comprehensive macroeconomic and financial statistics based on best dissemination practices, facilitating the pursuit of sound macroeconomic policies. By joining this initiative, governments signal their commitment to disclose policy-relevant data. Has the SDDS initiative served its purpose? We provide first quantitative evidence on the effects of the SDDS data transparency initiative. We use Hollyer, Rosendorff and Vreeland's (2014) Data Transparency Index which gauges governments' ability to collect and disseminate aggregate economic data using a Bayesian item response algorithm model, which treats transparency as a latent predictor of the reporting (absence) on 240 variables collected from the World Bank's World Development Indicators. Using panel data on 120 countries during the 1996-2011 period, we find that countries complying with the SDDS initiative are associated with an increase in data transparency index after controlling for self-section bias. Our results are robust to controlling for endogeneity using instrumental variables, alternative sample, and estimation methods.
\end{abstract}

Keywords: Data transparency, SDDS initiative, IMF.

Authors’ note: We thank Niklas Potrafke, Kai Gehring, and Noel Johnston for some suggestions. 


\section{Introduction}

Do transparency initiatives work? More specifically, do initiatives to promote data transparency improve the governments’ willingness to disclose basic policy-relevant data? In this paper, we quantify explicitly, information asymmetries by compliance of a country with the Special Data Dissemination Standard (SDDS hereafter) program initiated by the International Monetary Fund (IMF or Fund henceforth) to enhance the availability of timely and comprehensive macroeconomic and financial data based on best dissemination practices; which facilitate countries' pursuit of sound macroeconomic policies and access to and functioning of international capital markets (SDDS guide 2007). Launched in 1996, the main objective of the program is to increase the data transparency of participant countries to release accurate data frequently to market participants and the public at large. By joining this initiative, governments signal their commitment to be transparent, readily disclosing and disseminating policy-relevant data in the public domain, which reduces the cost for market participants to access information.

Has the SDDS initiative served its purpose? While there is some anecdotal evidence to suggest that compliance with the SDDS program has led to an increase in transparency of participant countries, empirical evidence on the same remains scant. This is the gap in the literature this paper seeks to fill, by providing first quantitative evidence on whether the variation in data transparency among countries can be explained by accession to the SDDS initiative. A large number of studies in the literature have highlighted the importance of data transparency in attracting foreign investment, reducing herd behavior, lowering market volatility, borrowing costs, improving forecasts and even corporate earnings (see Graham, Johnston, Kingsley 2014, 2013, Hashimoto and Wacker 2012, Brennan et al 2005, Gelos and Wei 2005, Easley and Hara 2004, Core 2001, Diamond and Verrechia 1991). Thus, it can be 
argued that compliance of a country with transparency promoting initiatives such as the SDDS program on releasing accurate data affects the actual level of transparency in the country.

While previous studies have looked at various measures of transparency, in the present study, we are interested in measuring the actual level of transparency of a country in disclosing timely and accurate basic economic data. We thus rely on Hollyer, Rosendorff and Vreeland's (2014) Data Transparency Index which gauges a governments' ability to collect and disseminate aggregate economic data using a Bayesian item response algorithm model, which treats transparency as a latent predictor of the reporting (absence) on 240 variables collected from the World Bank’s World Development Indicators. Accession to the SDDS initiative could be an important factor explaining the country level variation in the Hollyer et al. (2014) Data Transparency Index. A data transparency initiative such as the SDDS would not only make access to information easier but also reduce the cost to access data. This reduces duplicity and provides authentic data to the public at large and market participants. From a government's point of view, accession to SDDS could serve as a 'commitment device' to signal the domestic constituents and international community of the increased level of data transparency. Moreover, the credibility of a country as an investment destination would improve because often market participants' decisions are based on timely access to reliable macroeconomic and financial data. Investors often lack time and resources to collect the data they need (Gelos and Wei 2002) and have to deal with untimely, irregular and lack of authenticity of information provided by domestic institutions (Fratzscher and Reynaud 2011). We thus expect that as countries comply with the SDDS program, a government's willingness to disclose and disseminate policy-relevant data to improve.

Using panel data on 120 countries over the 1996-2011 period, we find that countries complying with the SDDS initiative are associated with an increase in the data transparency 
index after controlling for self-section bias using a treatment regression estimator. These results are robust to controlling for selection bias, fixed effects and endogeneity using the instrumental variables approach. These results also survive a wide-variety of robustness checks including alternative data, a sample of developing countries alone, and testing methods such as the Feasible Generalized Least Squares (FGLS) fixed effects method.

This paper contributes to the literature on transparency and the IMF in several ways. First, the IMF's role as an information provider has been studied extensively in the literature (see: Sahin 2012, Fratzscher and Reynaud 2011). However, most of these studies examine the effectiveness of information and assessment reports from the Fund in several ways, without actually emphasizing as to where this information and data are obtained from in the first place. This paper aims to contribute to this strand of literature by examining whether membership in a data transparency program initiated by the IMF affects data transparency behavior of respective governments. Second, in doing so, we also try understand as to why countries join and comply with the data transparency program initiated by the Fund. Third, there is a growing body of literature analyzing the importance of transparency in governance and economic policies (Bussell 2010, 2011, Berliner 2012, Costa 2013, Vadlamannati and Cooray 2014, Berliner 2014, Berliner and Erlich 2015). These studies examine transparency in politics and economic institutions, but do not analyze the effect of SDDS in promoting data transparency, i.e. providing authentic economic data and financial information on a country. To the best of our knowledge, we know of no other empirical study that addresses this question. Finally, we are able to disentangle the data transparency effects of joining the SDDS program from the institutional features of a country. It is plausible, as noted by Glennerster and Shin (2007), that countries which are inherently more transparent in nature would be the ones which might comply with a data transparency initiative like the SDDS program. Fortunately, we are able to isolate the effects of the SDDS program because different 
countries in our sample have joined and complied with the initiative at various points of time. Thus, we are able to use this variation over time for a given country to examine the impact of the SDDS program irrespective of that country's institutional features. Like Glennerster and Shin (2007), we also use country fixed effects to pick up long-run correlates of transparency, and time specific dummies to control for the general time trend. We thus identify the impact of complying with the SDDS program by examining whether a particular country which complied with the program earlier, is more transparent than other countries which do not comply.

The rest of the paper is structured as follows. In the next section, we present an overview of related literature on the importance of the SDDS initiative launched by the IMF and its impact on data transparency. Section 3 describes our data and estimation strategy. Section 4 presents the results and discussion, and section 5 concludes.

\section{An Overview of the SDDS initiative and Data Transparency}

There is a large body of literature in financial economics, highlighting the importance of access to accurate data. Nobel laureate Stiglitz (2000) highlights that informational asymmetry is the key to explaining why markets fail and are imperfectly competitive. Building on this argument, the Morris-Shin model finds that imperfect information could be welfare-reducing when market participants are faced with information asymmetry problems or noisy information (Morris and Shin 2002). The Morris-Shin model has been used extensively in the financial economics literature in the context of the role of data released by governments and central banks, to examine the effect on market expectations and volatility (see: Bikhchandani et al. 1992, Banerjee 1992, Gherig 1993, Brennan and Cao 1997, Kang and Stulz 1997, Bikhchandani and Sharma 2000, Chordia and Shivakumar 2006). Likewise, there is also evidence to show that international portfolio investors react favourably to an improvement in a country's level of transparency. For instance, Hashimoto and Wacker 
(2012) find that countries subscribing to transparency initiatives witness an increase portfolio and direct foreign investments. Similarly, Berliner (2012) finds that transparency initiatives to promote accountability tend to attract FDI inflows in the long run. ${ }^{1}$ Disaggregating foreign investments by its two largest segments namely, bank debt and direct investment by firms, Graham, Johnston, Kingsley (2014, 2013) find that banks are better equipped at managing transfer risk because they have better access to local private information.

A noteworthy theme of these studies is that the data is made readily available in the public domain by the government in the first place. In other words, these studies assume that governments might actually be willing to share information and release accurate data rather than withholding it from the public. While most of these studies have thus far concentrated on the importance and consequences of accurate data, focus on the supply-side of data provision (and quality of data) remain scant. Of late, few studies examined the determinants of data transparency (and transparency in general). The underlying principle of most of these studies is that political factors determine the government's actions of withholding information from the public. Berliner (2014) finds in a cross-national study that a competitive political environment shapes the incentives for political actors to introduce transparency initiatives. Examining within country variations in South Africa and Mexico reveal similar findings (see: Berliner and Erlich 2015, Berliner 2015). Focusing on data transparency in particular, Williams (2009) in a study of 171 countries, finds that the release of data by the government explains improvement in bureaucratic quality, investment and financial sector development in the short as well as in the long run. Hollyer et al. (2011) examining the determinants of data transparency of governments find that democracy is a key prerequisite in explaining the variation in data transparency among countries. Extending the analysis on data transparency

\footnotetext{
${ }^{1}$ Gelos and Wei (2002) also find that lack of transparency has a negative influence on economic performance of a country thus lowering the level of international investments. Similar such findings are corroborated by the IMF (2001), Frenkel and Menkhoff (2004).
} 
further, Hollyer et al. (2015) find that data transparency destabilizes autocratic regimes through mass protests and demonstrations.

Thus, recognising this need, the IMF initiated a series of reforms to increase transparency especially in developing economies, to address the concerns of not only market participants, but also policy makers on the lack of access to reliable basic economic data and financial information. Thus, the Special Data Dissemination Standard initiative was launched by the Fund in the year 1996. The aim of this initiative was to help member states of the IMF, in accessing international capital markets to raise funds, provide economic and financial data to market participants, and the public at large (see SDDS guide 2007). In other words, the SDDS initiative aims to enhance the availability of timely and comprehensive economic and financial data to policy makers and market participants, and is expected to contribute to economic policy assessments in pursuit of sound macroeconomic policies, thus facilitating public and private decision making (see SDDS/IMF 2013). The lack of data transparency among countries during the financial crises of the 1990s, has contributed to the delay in corrective action that could have been taken according to the IMF. For instance, the IMF policy brief (2001) points out that, "lack of transparency was a feature of the buildup to the Mexican crisis of 1994-95 and to the emerging market crisis of 1997-98. During these crises, markets first became uncertain as they were kept in the dark on important developments, and then were struck by a web of interlocking problems. Inadequate economic data, hidden weaknesses in financial systems, and lack of clarity about government policies and policy formulation contributed to a loss of confidence that ultimately threatened to undermine global stability.”2 In response, the SDDS data transparency initiative was introduced to enhance not just the quality but also the range and timeliness of country data availability.

\footnotetext{
${ }^{2}$ See: http://www.imf.org/external/np/exr/ib/2001/042601b.htm
} 
The SDDS identifies four dimensions of economic and financial data dissemination, which includes: (a) data coverage, period of coverage and timeliness; (b) access by public; (c) integrity of disseminated data; and (d) quality of data disseminated (SDDS guide 2007). The SDDS program establishes data dissemination in four important sectors of the economy, viz., the real sector, fiscal sector, financial sector and the external sector, considered most important for assessing macroeconomic performance and policy. Within these four sectors, 18 different indicators are identified as important. ${ }^{3}$ The SDDS prescribes the frequency and timeliness with which data for these 18 indicators in four key sectors are to be disseminated. Within these 18 indicators, some are marked as 'relevant' ${ }^{4}$ and others as 'encouraged' for dissemination of data. The program emphasizes transparency in the compilation and dissemination of data. ${ }^{5}$ The data dissemination of 18 indicators in these four sectors is the minimum requirements for entry into the program. The countries willing to subscribe to the SDDS initiative are further encouraged by the IMF to disseminate additional data on various other economic and financial indicators that may increase the transparency of their economic performance and policies.

Joining the SDDS program involves three stages. In the first stage, countries interested in joining are communicated to, by the Secretary of the IMF. It is noteworthy that the SDDS subscription is voluntary and there is no pressure to join. Subscription to the program opened in 1996 through a letter from the IMF's Managing Director sent to all IMF member countries (SDDS guide 2007). Entry into the program carries a commitment by the subscribing member states to observe the various dimensions and elements of the SDDS and also to provide all the economic and financial data processing practices to the Fund. Upon entry, the member

Details on 18 indicators within these four broad sectors are provided here: http://dsbb.imf.org/pages/sdds/DataDimensions.aspx

${ }^{4}$ According to the IMF, 'relevant' in the SDDS context refers to data components that are specific to each country and vary across countries.

5 For more detail on data dissemination and monitorable elements of SDDS, see: http://dsbb.imf.org/Pages/SDDS/Overview.aspx\#dimensions 
country is then urged to provide all the necessary data for dissemination on the Dissemination Standards Bulletin Board (DSBB hereafter) as a part of the second stage process. The DSBB is maintained by the IMF which collects information on data and dissemination practices of member states (known as metadata) and it is then posted on an electronic bulletin board (SDDS guide 2007). Thus, inclusion of the list of countries on the bulletin board is an indication that the country concerned meets the criteria for transparency. Note that the responsibility to maintain accuracy of the metadata, and periodical updates is solely under the preview of the member state (SDDS guide 2007). The member state must also certify the accuracy of all metadata posted on the DSBB on a quarterly basis to the IMF staff. The member state's metadata however is up for review by a team of experts at the IMF looking into comprehensiveness and international comparability (SDDS guide 2007). In the final stage, the IMF staff will identify if there are any changes required to be made by member states to bring data dissemination practices in line with the SDDS initiative. The member state can work on these changes and revert back to the IMF. Upon verification of the changes by the IMF staff, the member state is allowed to subscribe to the program. On the other hand, if the IMF staff determines that no changes are needed in the first review on the data provided, the member state proceeds to inform the secretary of the IMF of its formal subscription.

Appendix 2 provides details of the countries which have subscribed to the SDDS initiative. In total, about 70 countries have subscribed to the SDDS program. Appendix 2 also provides details on the date of joining the program along with the date in which the metadata was posted on the electronic bulletin (DSBB) and date of final subscription. Note that in some instances the data of the DSBB and date of final subscription are similar. This is because these countries were not required to make further changes to their data dissemination practices when information was provided for the purpose of posting on the DSBB. It is also noteworthy that all the 70 countries which entered into the program have also complied with the program. 
In total, out of 70 countries, 20 countries are from the high income OECD group. The importance of the SDDS transparency initiative is already being examined by some scholars. Both Cady (2005) and Glennerster and Shin (2007) examine the relationship between access to the SDDS initiative and the price of international financial capital. Both find that SDDS membership is associated with lower borrowing costs in sovereign bond markets. In addition, Glennerster and Shin (2007) also find that smaller countries with less liquid debt markets were direct beneficiaries because the private sector has less incentive to monitor the availability of accurate information. With respect to foreign portfolio and direct investments, Hashimoto and Wacker (2012) find that joining the SDDS program, in addition to reducing borrowing costs, has a positive influence. Thus, if complying with the SDDS program reduces borrowing costs, improves forecasts and increases foreign investments, then it could be argued that these effects are transmitted through improvements in actual data transparency led by governments' willingness to disclose policy-relevant data in the first place. So far, there is no systematic empirical work that has explicitly modelled whether variation in actual data transparency among countries can be explained by a country's accession to the SDDS initiative.

We argue that complying with the SDDS initiative can improve the data transparency of a country which in turn brings numerous benefits. First, a country’s entry into transparency promoting initiatives like the SDDS acts as a commitment devise that signals the government's intent to disclose policy-relevant data. This enhances a country's credibility because often market participants have to deal with irregular and problems of authenticity regarding information provided by domestic institutions (Fratzscher and Reynaud 2011). Second, improvement in data transparency led by the SDDS initiative will be helpful for external agencies such as the IMF and credit rating agencies to monitor a country's performance on economic policy, which in turn has a decisive impact on investment decisions 
of institutional investors (Marchesi 2003 and Marchesi and Thomas 1999). In fact, Sahin (2012) show that country reports prepared by the IMF based on data monitoring has a favorable impact on investor perception. ${ }^{6}$ Also, Fratzscher and Reynaud (2011) examine the surveillance announcements in Public Information Notices (PIN) of the IMF gathered from the data provided by governments on investor behavior in 36 emerging markets. They find that financial markets respond favorably to PIN announcements made by the Fund. ${ }^{7}$ Third, the SDDS program provides incentives for countries in need of short-term external finance to promote transparency because such measures will lead to more sound policies in the long-run (Berliner 2012, Hashimoto and Wacker 2012). Moreover, lack of access to basic macroeconomic data leads to uncertainty in the minds of investors resulting in high premiums due to additional costs incurred in accessing and monitoring data. In the next section, we put these arguments to an empirical test wherein, we examine whether complying with the SDDS initiative indeed leads to increased data transparency.

\section{Data and Methods}

\subsection{Model Specification}

We use panel data covering 120 countries (see Appendix 1) over the 1996-2011 (16 years) period, to examine the impact of the SDDS program subscription on data transparency. Since the SDDS program was initiated only in 1996 by the IMF, our study covers the period from 1996 onward. However, estimating the impact of the SDDS program on data transparency is not straightforward because entry into, and compliance with the SDDS program are not random events. Rather, countries decide whether or not to participate and comply with such a voluntary program leading to a self-selection problem. Thus, estimation

\footnotetext{
${ }^{6}$ Hoekman and Saggi (1999) show that even direct foreign investors base investment decisions on their perceptions of economic fundamentals which include access to data on macroeconomic conditions such as current and future economic growth, inflation, balance of payments and government finances, interest rates and exchange rate trends, among others.

${ }^{7}$ However, Tong (2007) challenges the conventional wisdom on transparency in his study which argues that public disclosure will crowd out private investment.
} 
using Ordinary Least Squares (OLS) models would lead to a selection bias. To circumvent this problem, we use a binary treatment regression estimator to control for selection effects. ${ }^{8}$ The treatment regression estimator takes account of the determinants of a country's decision to subscribe to the SDDS initiative, the non-random treatment assignment, and models it in non-linear specifications. The non-linear prediction equation for SDDS compliance and the linear estimation of data transparency determinants are estimated simultaneously. Note that the major difference between a treatment regression estimator and Heckman selection estimator (Heckman 1979) is that while the former observes both outcomes of the binary decision, the later only explicitly considers observations of the outcome of interest. The treatment regression estimator is the most appropriate in our case, because it enables us to analyse whether countries which have adopted the SDDS initiative are more transparent in disclosing economic and financial data compared to those who are not part of the program after controlling for the selection effects of the SDDS program. The two-step treatment regression specification estimates the probability of a country $i$ in joining and complying with the SDDS program in year $t$ in the first step which is a non-linear specification, and the impact of complying with the SDDS program on data transparency in country $i$ in year $t$ in the second step which is a linear specification:

$$
\begin{aligned}
& \text { SDDS } \operatorname{comp}_{i t}=\phi_{i}+\beta Z_{i t}+\lambda_{t}+\omega_{i t} \\
& \text { DTI }_{i t}=\phi_{i}+\beta_{1} \text { SDDS } \text { comp }_{i t}+\beta_{2} Z_{i t}+v_{i}+\lambda_{t}+\omega_{i t}
\end{aligned}
$$

Wherein, SDDS comp is a discrete variable taking the value 1 in the year $t$ if country $i$ complies with the SDDS program and 0 otherwise. About 64 countries in our sample have joined the SDDS program in different years since 1996 (see Appendix 2 for the list of countries). Figure 1 captures the development of the SDDS program during the 1996-2011

\footnotetext{
${ }^{8}$ We make use of the etreg command in Stata 13 to estimate treatment regression models.
} 
period. As seen, though the compliance in the initial years of the program was slower, about $50 \%$ of the sample of 120 countries, almost all the signatories have complied with the SDDS program as of 2011.

In choosing the determinants of a country's compliance with the SDDS program in the first step, we include GDP per capita, measured in 2000 US\$ constant prices (logged) as a measure of the income level sourced from the UNCTAD statistics (2014). We expect richer countries to be more willing to join such transparency initiatives. Second, previous studies on the transparency initiative show that democracies are more transparent vis-à-vis autocracies especially in disseminating data (see Hollyer et al. 2011, Jakobsen and de Soysa 2006). We thus include a measure of democracy based on the Marshall and Jaggers (2002) polity IV index ${ }^{9}$ which is recoded as 1 if the Polity IV index is above +5 on the scale of -10 to +10 with higher values representing full democracy, and 0 otherwise. ${ }^{10}$ Likewise, we also create a dummy measure for autocracy which takes the value of 1 if the Polity IV index is below -5 and 0 otherwise. In addition to these variables, we include a dummy variable if a country is experiencing one of the three or all of the three: currency, debt and systematic banking crises, sourced from Laeven and Valencia (2008, 2013), which is expected to have a positive effect if a country joins such a transparency initiative. Following Berliner (2014), we include a measure of trade openness using total trade as a share of GDP obtained from the UNCTAD statistics (2014). We expect more open economies to be willing to join such transparency initiatives. We also control for corruption in our model using the corruption index coded on a scale of -2.5 to +2.5 in which a higher value denotes a lower level of corruption, from the World Bank Governance indicators (2014). The relationship between corruption and government's willingness to participate in transparency promoting initiatives is not very clear.

\footnotetext{
${ }^{9}$ Though the Polity IV index has faced some criticism (see Potrafke 2012), it captures three important elements of democracy namely, presence of institutions, existence of effective constraints on executive and participation in political process, which are found to be key for economic openness (Vadlamannati 2012).

${ }^{10}$ Note that estimating the models directly with the Polity IV index does not alter our results much.
} 
Some believe that the government's intent to undertake transparency initiatives depend directly on the extent of political corruption in the country (see Bussell 2011, Berliner 2014, Berliner and Erich 2015). However, it is also plausible that governments under pressure from the electorate to tackle corruption may undertake transparency measures (Vadlamannati 2014). Vadlamannati and de Soysa (2015) argue that resource rich countries are less likely to promote transparency laws. Furthermore, these studies find that even if countries promote transparency laws, such laws tend to be weaker. Thus, we include a measure of natural resource rents as a share of GDP from the World Bank's World Development Indicators (World Bank 2014). ${ }^{11}$ Accordingly, the World Bank defines resource rents as unit price minus the cost of production times the quantity produced. Finally, we include a dummy if country $i$ participates in the IMF structural adjustment program in year $t$ as a measure of external influence as the SDDS program is initiated by the IMF. We obtain the IMF program participation dummy variables from the dataset developed by Boockmann and Dreher (2003) and Dreher (2006). Note that in the first step, we include time fixed effects. However, we do not control for country-specific fixed effects in this non-linear estimation due to the incidental parameter problem (see: Lancaster 2000, Wooldridge 2002).

In the second step we use the Data Transparency Index of country $i$ in year $t$ as our dependent variable ( $D_{i t}$ ) sourced from Hollyer, Rosendorff and Vreeland (2014). The index measures the public disclosure of credible economic information by respective governments. Thus, the aim of the Hollyer et al. (2014) index is to capture a specific dimension of government's transparency namely, governments' collection and dissemination of aggregate data. In order to construct the index, Hollyer et al. (2014) use a Bayesian item response algorithm (IRT) model which treats transparency as a latent predictor of the reporting or absence of the data on 240 variables collected from the World Bank's World

\footnotetext{
${ }^{11}$ This data are accessed from the World Development Indicators 2014. For a detailed explanation of methodologies and the calculation of rents, see: http://databank.worldbank.org/data/
} 
Development Indicators (WDI hereafter). Thus, the index is a continuous measure ranging from -10.9 to +10 , over the $1980-2010$ period, in which higher scores denote greater disclosure of the government on 240 variables from the WDI. ${ }^{12}$ We use this index due to two specific advantages. First, unlike other measures (for instance see Williams 2014) who use a simple average to construct similar such data transparency measures, the Hollyer et al. (2014) index uses a more sophisticated item-response algorithm to produce a continuous measure of data transparency. Second, because they rely on 240 variables from the World Bank’s WDI, this index is more objective rather than other indices which are derived purely based on experts' opinions/analysis. Figure 2 captures the evolution of the data transparency index during the 1980-2010 period. ${ }^{13}$ As seen, the transparency index has steadily increased from the 1980s onwards. The increase in the index surged during the 1990s (the post-Cold War period), only to decline during the post global financial crises years.

With respect to the control variables, we follow other studies on determinants of data transparency - Hollyer et al. (2014), Williams (2014), Hollyer et al. (2011) and Williamns (2009). Accordingly, we include GDP per capita, measured in 2000 US\$ constant prices (logged), as a proxy for the level of development in a country. We expect per capita GDP to have positive effect on data transparency. As before, we also include two measures capturing the regime type namely, a democracy and autocracy dummies. Hollyer et al. (2011) find that both level of income and democracy are robust determinants of data transparency. We include a dummy to capture whether a country is in economic crises or otherwise. We also include a measure of trade openness as before to account for the possibility that integration with the global economy leads to greater data transparency (Berliner 2014). Finally, we also include natural resource rents as a share of GDP as described above to assess whether resource rich

\footnotetext{
${ }^{12}$ For a detailed description of the computation of this index, see Hollyer, Rosendorff and Vreeland's (2014) work. Further details on the index are available at: http:/hrvtransparency.org/

${ }^{13}$ Note that the study period of this paper is from 1996-2011 but the Data Transparency Index constructed by Hollyer et al. (2014) is available from 1980 to 2010.
} 
countries are more transparent in disclosing data compared to their non-resource rich counterparts.

Note that we do not include a lagged dependent variable as inclusion of one according to Achen (2000) can drastically reduce the explanatory power of the independent variables. Including a lagged dependent variable in a short panel (15 years) with fixed effects causes inconsistent estimations resulting in a downward bias of the coefficient, known as the 'Nickell bias' (Nickell 1981). Thus we estimate all our models without the inclusion of a lagged dependent variable. We address this concern using the System-GMM approach. Note that in the second step of the treatment regression estimators, we control for both time and country fixed effects. Along with treatment regressions, we also run our regressions using the Feasible Generalized Least Squares (FGLS henceforth) method. Using FGLS over a simple OLS allows estimations in the presence of AR (1) autocorrelation within panels and cross-sectional heteroscedasticity across the panels. The descriptive statistics on all the afore-mentioned variables are reported in Appendix 3 and the details on definitions and data sources are provided in Appendix 4.

\subsection{Endogeneity concerns}

It is quite possible that our key explanatory variable -compliance with the SDDS program - is endogenous to having higher levels of data transparency. Countries which are more transparent in disclosing macroeconomic and financial data to international organizations might be more willing to join transparency promoting initiatives such as the SDDS program. Not taking this endogeneity into account, would induce bias in our estimate on the effect of compliance with the SDDS program on data transparency. In order to address this endogeneity concern, we utilize two-stage least squares instrumental variable (2SLS-IV henceforth) estimations. We use two instruments to account for the endogeneity problem. First, following Costa (2013) we use the share of neighboring countries in the geographic 
region that have complied with the SDDS program in year $t$. We believe that this instrument is likely to be highly correlated to whether a country complies with the SDDS program, but is most unlikely to be correlated with the data transparency index. The idea of peer effects influencing the likelihood of a country's participation in such a transparency initiative is not new to the literature. Similar such diffusion measures are used by Simmons and Elkins (2004) in assessing diffusion in financial policy among countries. Gassebner et al. (2011) find that a country's economic policy reforms are affected by reforms adopted by its neighboring countries. Likewise, Eichengreen and Leblang (2008), in their study on democracy and economic openness, instrument capital account openness with a lagged value of capital account openness of peers. ${ }^{14}$ In the specific case of transparency laws, which is much closer to our main variable of interest, Costa (2013) finds that the adoption of FOI laws by a country is explained by whether neighboring countries in the region adopt similar such laws. Similarly, Berliner (2013) examines FOI laws in 4096 country pairs, and finds that countries belonging to the same geographic region tend to have similar FOI laws compared to other country-pairs. These studies in the area of transparency laws show that regional emulation plays an important role in shaping the transparency of policy.

Second, previous literature on the IMF show that the major shareholders of the Fund influence the IMF to favor certain countries, in return for votes at the United Nations General Assembly (UNGA hereafter) (see Dreher, Sturm 2012, Barro and Lee 2005, Stone 2004, Thacker 1999). Since the SDDS program was initiated by the IMF in 1996 with the support of the US, it is plausible that countries which vote in line with the US in the UNGA, are not only rewarded with IMF lending, but also undertake other initiatives launched by the IMF and supported by the US. Thus, we use the UNGA voting alignment index as our second instrument. The UNGA voting alignment index is developed by Voeten (2000) and Voeten

\footnotetext{
${ }^{14}$ Cooray, Tamazian and Vadlamannati (2014) have also done this in the context of FDI policy liberalization.
} 
(2004) and updated by Strezhnev and Voeten (2012). The Strezhnev and Voeten (2012) measure codes votes in agreement with the US as 1 , votes in disagreement as 3 , and 2 for abstentions. The resulting numbers are then divided by the total number of votes in the UNGA each year, resulting in a measure coded between 0 and 1 . Note that when using the UNGA voting alignment index, the index for the US is treated as missing.

The validity of the selected instruments depend on two conditions. The first is instrument relevance, i.e., they must be correlated with the explanatory variable in question. The joint F-statistic in the first stage of the IV regressions as suggested by Bound, Jaeger and Baker (1995) must be examined to test the relevance of the instruments. Thus, the instruments would be relevant when the first stage regression model F-statistics meet the thumb rule threshold of being above 10 (see: Staiger and Stock 1997). However, the F-test has been criticized in the literature as being insufficient to measure the degree of instrument relevance (see: Stock et al. 2002, Hahn and Hausman 2002 and 2003). The more powerful test of CraggDonald Wald F-statistic and Kleibergen-Paap rk LM F-statistic are also suggested (CraggDonald 1993, Kleibergen-Paap 2006). In both cases, the F-statistic above the critical value (10\% maximal test size) indicates the rejection of weak instruments. Second, the instrumental variables should not vary systematically with the disturbance term in the second stage equation, i.e. $\left[\omega_{i t} \mid I V_{i t}\right]=0$. Meaning, the instruments cannot have independent effects on the dependent variable. As for the exclusion restriction, we are not aware of any theoretical or empirical argument linking the afore-mentioned exogenous instrumental variables directly impacting the data transparency index of country $i$. Nevertheless, the Hansen J-test (Hansen 1978) is employed to check whether the selected instruments satisfy the exclusion restriction (statistics reported at the end of Table 4). 


\section{Empirical Results}

Tables 1-5 present our main results. Table 1 presents results for the global sample, while Table 2 reports results for only developing countries. Table 3 shows results controlling for other key determinants of data transparency. Table 4 presents the results for both the global sample and developing countries sample controlling for endogeneity concerns using 2SLS-IV estimations. We begin by presenting some simple stylized facts on the data transparency initiative. Figure 3 provides a first descriptive look at the effect of the SDDS initiative on data transparency. The figure compares the performance of the data transparency index of those countries that did not join the SDDS initiative during the sample period vis-àvis those that did. As seen, countries that complied with the SDDS program on average demonstrate higher data transparency compared to those that did not. For instance, countries under SDDS initiative score of 4.2 points on the data transparency index compared to those with only 0.37 points scored by non-compliant countries, indicate a difference of roughly 3.8 points which is about $196 \%$ of the mean value of the data transparency index (see descriptive statistics in Appendix 3) during the 1996-2010 period. Notice that when excluding the developed countries from the sample, we find that those developing countries which complied with the SDDS initiative tend to have a higher levels of data transparency vis-à-vis countries that have not joined the program. One might conclude from these stylized facts that compliance with the SDDS is associated with higher levels of data transparency. These simple bivariate statistics, however, may lead to spurious conclusions without controls, such as income, or the lack of democracy, rather than compliance with the SDDS program, in explaining differences. Thus, we move next to examine the statistical relationship in greater detail and precision in multivariate models.

Starting with Table 1, we first examine the effect of compliance with the SDDS program in a parsimonious model without controls in column 1, followed by controlling for 
basic control variables in column 2, and including all possible control variables in column 3 using treatment regressions. We replicate these results using the FGLS fixed effects estimator in column 4-6. As can be seen in column 1, we do find a positive significant effect of compliance with the SDDS program on the data transparency index, which is significantly different from zero at the $1 \%$ level. The substantive effects suggest that countries that comply with the SDDS on average, experience an increase in the data transparency index by roughly 0.9 points (see column 1 ) which is about $47 \%$ of the mean value of the transparency index. Note that these results are estimated using treatment regression estimations which already control for factors influencing why countries join and comply with the SDDS program. When controlling for income and regime type variables in column 2, our results on SDDS program compliance remain robust. Countries that comply with the SDDS initiative witness on average an increase in the data transparency index by roughly 0.86 points (see column 1 ) visà-vis those which did not join the program. Both income and democracy have the expected positive effects and are statistically significant, net of SDDS compliance. For instance, a standard deviation increase in per capita income (log) is associated with about a 1.3 point increase in the data transparency index, which is significantly different from zero at the $1 \%$ level. Likewise, being a democracy is associated with a 0.31 point increase in the data transparency index, which is significantly different from zero at the $1 \%$ level. Interestingly, autocracy has no significant effect on promoting data transparency. These results are broadly in line with the findings of Hollyer et al. (2011), that electoral politics provide incentives for governments to disseminate data. Controlling for a range of other variables in column 3 do not alter our main results. As seen, once again, compliance with the SDDS program variable remains positive and statistically significant at the $1 \%$ level. Notice that apart from income and democracy, we also find that resource rich countries are less likely to be transparent. For instance, a standard deviation increase in rents/GDP above mean, is associated with about a 
0.13 point decline in the data transparency index, but having no rents from resources to increasing rents/GDP by the maximum value in the sample would lower the data transparency index by about 0.76 points. In fact, these results are broadly in line with the findings of Vadlamannati and de Soysa (2015) who find that countries deriving rents from natural resource are less likely to adopt Freedom of Information (FOI) laws. Overall, these results highlight two important points. First, entry into the SDDS transparency program is beneficial to compliant countries, which supports our main argument. Second, when dealing with the SDDS program, what matters is compliance and not merely joining the program. Complying with the SDDS initiative suggests providing full data disclosure to international agencies such as the World Bank, IMF and the United Nations, among others, which is then made easily accessible to market participants and the public at large.

The lower part of column 1-3 in Table 1 shows the results of the non-linear treatment regression that estimates the probability of complying with the SDDS initiative. As seen, richer countries tend to comply with the SDDS initiative. However, we do not find any significant positive effect for democracy, but we do find that a strong negative effect of autocracy on SDDS compliance. Surprisingly, we find a negative effect of trade openness on SDDS compliance suggesting that countries which are already more open to trade are less likely to comply with the SDDS initiative. Next, there is no empirical support for the argument that countries ridden with macro-economic and financial crises would join transparency initiatives. Also, participation in IMF programs alone do not seem to have any effect on complying with the SDDS initiative. Likewise, we do not find any support that countries with higher levels of corruption are less likely to join transparency initiatives. The effect of the corruption index on SDDS compliance is statistically insignificant. Finally, we do find that resource rich countries are less likely to comply with the SDDS initiative. This finding is similar to that of Vadlamannati and de Soysa (2015). A standard deviation increase 
in resource rents/GDP, holding all controls constant at their mean, are 52\% less likely to comply with the SDDS initiative, which is significantly different from zero at the $1 \%$ level.

We now estimate the SDDS compliance model with the FGLS two-way fixed effects estimation specification reported in columns 4-6, Table 1 . As seen from column 4, SDDS compliance is positive and significantly different from zero at the $1 \%$ level. However, notice that the effect of compliance on the data transparency index has been halved from 0.9 to 0.42 points. These results suggest that not accounting for the selection bias problem would systematically underestimate the impact of the SDDS initiative on data transparency. Moving further to column 4, our results remain robust when controlling for the level of income and regime type. Once again, income and democracy are positive and significantly different from zero at the $1 \%$ level, supporting the findings of Hollyer et al. (2011). Finally, in column 6, the results of SDDS compliance on increasing data transparency remain robust when including other plausible explanatory factors. The effects of democracy and income also remain robust. These results show that the effect of SDDS compliance in promoting data transparency is robust to alternative estimations and controlling for a range of explanatory variables.

In Table 2 we replicate the estimations reported in Table 1 with a restricted sample in which we exclude high income OECD countries which have complied with the SDDS initiative, and are equipped with well-developed and sophisticated institutional mechanisms in place to ensure data transparency. These include: Australia, Austria, Belgium, Canada, Denmark, Finland, France, Germany, Greece, Italy, Ireland, Netherlands, New Zealand, Norway, Portugal, Spain, Sweden, Switzerland, UK, and the USA. It is quite plausible that our results might be driven by these countries which comply with the SDDS program but also fare well in terms of data transparency. As seen from Table 2, in line with our expectations, compliance with the SDDS is associated with an increase in data transparency (see columns 1-6). On average, countries, excluding high income OECD countries, complying with the 
SDDS initiative are associated with a 0.82 points increase in the data transparency index, which is significantly different from zero at the $1 \%$ level (see column 1). As seen from column 2, these results are robust to including income and regime type variables. Also note that the level of income and democracy are positive and statistically significant at the $1 \%$ level. Thus, the net effect of SDDS program compliance (net of income and regime type) in developing countries is strongly positive. Finally, in column 3, additional control variables do not change our results very much. Controlling for other plausible explanatory factors, SDDS compliance for developing countries is associated with a 0.74 point increase in the data transparency index. Note that these results are based on treatment regression estimations which already control for factors influencing countries complying with the SDDS program. By and large, these results suggest that even among developing countries alone, the impact of SDDS program compliance is positive. As our results for this restrictive sample group of developing countries are comparable to those with the full sample, we believe that our results are not driven by the inclusion of the high income OECD countries in the sample whose performance on data transparency are relatively high. Note that these results on SDDS program compliance are robust when estimated using the FGLS fixed effects estimator, reported in columns 4-6 in Table 2.

In Table 3, we include additional explanatory variables, namely, economic policy reforms, and a general transparency index which might be influenced by compliance with the SDDS initiative and could be a key determinant of data transparency in turn. To measure economic policy reforms we make use of the economic freedom index (EFI hereafter) from the Heritage foundation. ${ }^{15}$ The EFI from the Heritage foundation is a comprehensive measure consisting of 10 freedom measures viz., property rights, freedom from corruption, fiscal freedom, government spending, business freedom, labor freedom, monetary freedom, trade

\footnotetext{
${ }^{15}$ Note that we prefer the economic freedom index from the Heritage foundation over the Fraser institute because of the coverage of data across 148 countries. Nevertheless, our results remain similar when replacing the economic freedom index of the Heritage institute with that of the Fraser institute.
} 
freedom, investment freedom and financial freedom which are in turn grouped under the categories of: rule of law, limited government, regulatory efficiency and open markets. Each of these 10 variables is transformed to an index on a scale from 0 to 100 . Higher values on the original variable indicate a higher degree of freedom; the formula $\left[\left(\mathrm{V}_{\mathrm{i}}-\mathrm{V}_{\min }\right) /\left(\mathrm{V}_{\max }-\mathrm{V}_{\min }\right)\right]$ $\times 100$ was used for the transformation. Conversely, when higher values indicated less freedom, the formula is $\left[\left(\mathrm{V}_{\max }-\mathrm{V}_{\mathrm{i}}\right) /\left(\mathrm{V}_{\max }-\mathrm{V}_{\min }\right)\right] \times 100$. These 10 indices are then averaged to derive the final index of economic freedom for each country. The final index is then ranked on a scale of 0 (not free) to 100 (totally free). We use this index as a proxy for economic policy making and promoting private sector development in a country. One of the key objectives of the SDDS program is not only to enhance the range, quality and timeliness of country data availability to the public and market participants, but also to provide better information to policy makers within these countries which help facilitate policy decision making. Thus, SDDS data transparency initiatives could also play a key role in economic policy assessments in these countries. Next, we also include a general transparency measure which reflects the level of transparency in the policies and institutions of a country. It could be argued that the willingness of a country to comply with the SDDS initiative could also usher more transparency in policies and institutions. Following Drabek and Payne (2001), we use the Political Risk Service (PRS) rankings ${ }^{16}$ from the International Country Risk Guide (ICRG) for the level of corruption, law and order, bureaucratic quality, contract viability and the risk of government expropriation of private assets which are combined to form a measure of the overall transparency index. ${ }^{17}$ Including these measures into our data transparency models closes possible transmission channels of an improvement in government policy

\footnotetext{
${ }^{16}$ It is noteworthy that there are other transparency initiatives such as the Corruption Perception Index (CPI) published by Transparency International. However, we do not use this measure of transparency as large numbers of countries in our sample are not covered for the initial years of the CPI. Also, the CPI measure is narrower compared to the measure we use from the PRS group.

${ }^{17}$ This is a weighted average index in which a $20 \%$ weight is given for the level of corruption, law and order, bureaucratic quality respectively, and a $40 \%$ weight is given to contract viability and risk of expropriation. The final index is coded on the scale of $0-10$ in which higher values denote transparency in policies and institutions.
} 
making when implementing SDDS standards. As seen from Table 3, the coefficients on these two variables are not significant at conventional levels whereas the effect of SDDS compliance remains significantly different from zero at the $1 \%$ level respectively. Notice that these results are consistent in both treatment regression and FGLS fixed effects regression estimations. These results once again support the argument that compliance with the SDDS initiative matters in promoting data transparency. However, this effect does not depend on perceived changes in economic policy decisions and general transparency in the system.

\subsection{Endogeneity}

We address endogeneity concerns using 2SLS-IV estimations reported in Table 4. Note that in columns 1-2 we present IV estimations for the global sample and in columns 3-4 we report results for the same, for the developing countries only. As seen from columns 1-2, we find the positive effect of SDDS compliance intact and significantly different from zero at the $1 \%$ level. The substantive effects suggest that moving from no SDDS program to complying fully with it is associated with roughly a 1.2 point increase in the data transparency index, which is about $63 \%$ of the mean value of the transparency index. These results remain robust when including all the explanatory variables into the model (see column 2). Note that Columns 1-2 in Table 4 also capture the results on the endogeneity tests - the joint F-statistic, CraggDonald Wald F-statistic, and Kleibergen-Paap LM F-statistic. The F-statistic of these tests from the first stage in both columns 1 and 2 reject the null that the instruments selected are not relevant. We obtain higher joint F-statistics (Cragg-Donald Wald F-statistic) of 323.7 and 285.6 (261.1 and 259.3, respectively), which are significantly different from zero at the $1 \%$ level reported in columns 1 and 2. Finally, the Hansen J-statistic (with p-values of 0.12 and 0.13) shows that the null-hypothesis of exogeneity cannot be rejected at the conventional level of significance. These tests confirm that we have avoided the weak instrument problem and that the results are robust. 
Notice that these results remain similar when excluding the high income OECD countries from the global sample (see column 3-4). The point estimate suggests that compliance with the SDDS initiative is associated with roughly a 2 point increase in the data transparency index for developing countries, which is significantly different from zero at the $1 \%$ level. These results do not change much when adding other explanatory variables into the model (see column 4). The F-statistic from the first stage in both columns 3 and 4, also reject the null that the instruments selected are not relevant. An interesting point here is that the point estimates have increased by almost two-fold in both samples once endogeneity is controlled for, using IV estimations. This suggests that the non-IV estimations were under estimating the effects of SDDS compliance. Taken together, our results remain robust to alternative estimations, sample and controlling for endogeneity.

\subsection{Checks on robustness}

We examine the robustness of our main findings in the following ways. First, we use an alternative estimation technique to address endogeneity concerns. We replace the 2SLS-IV estimator with the system-GMM estimation technique. We use system-GMM mainly to accommodate the lagged dependent variable, which is not included in earlier models. Inclusion of a lagged dependent variable leads to inconsistent estimates in a short panel with 15 years controlling for fixed effects, resulting in the 'Nickell bias' (Nickell 1981). We thus control for the lagged dependent variable by employing the system-GMM estimator as suggested by Arellano and Bond (1991), Arellano and Bover (1995) and Blundell and Bond (1998). We utilize Blundell and Bond's (1998) system-GMM estimator, which accounts for the Windmeijer (2005) correction, in which we use the previously discussed instruments as our main variable of interests, i.e. SDDS compliance. Furthermore, following the standard 
spatial econometric procedure, we lag the instruments by two years. ${ }^{18}$ As before, we include country-specific dummies, and following Roodman (2006), we collapse the instruments matrix to minimize the number of instruments in the system-GMM regressions. The results remain mostly unchanged, and SDDS compliance is positive and significantly different from zero at the $1 \%$ level. Second, we replace our dependent variable computed by Hollyer, et al. (2014) with the Information Transparency Index (ITI) computed by Williams (2014). The methodology used to compute the ITI is relatively less sophisticated than that of Hollyer, et al. (2014). The ITI index use a similar methodology as the Transparency International Corruption Perception index using indicators from about 29 different sources derived annually between the 1980-2010 period. $^{19}$ The ITI index captures both quality and quantity of information released from various sources and is coded on a 0-100 scale in which higher values denote higher transparency on information provided. When using the new ITI index as our dependent variable, the coefficients on the SDDS compliance variable remain positive and significantly different from zero at the conventional levels of statistical significance. It is noteworthy that we do not control for other variables when using the ITI index as the dependent variable, because several components used in constructing this index could include some of our control variables. This is another drawback of the ITI index. Thus, we estimate the models including only the SDDS compliance variable and control for country and time fixed effects. The results on the robustness checks are not shown here for the sake of brevity, but are available upon request. In summary, our results seem remarkably robust to using alternative data, sample size, specifications, and testing procedures.

\footnotetext{
${ }^{18}$ As a further check for robustness, we used different versions of lagged values for instruments. We lagged both variables by one and three years, respectively, and the results remained unchanged. Alternatively, we also use internal instruments. That is, we replace the two instruments discussed previously with lagged values of SDDS compliance as instruments. By and large, the results remain robust.

${ }^{19}$ For detailed information on methodology used, see: https://andrewwilliamsecon.wordpress.com/datasets/
} 


\section{Conclusion}

In this paper we examine the impact of the Special Data Dissemination Standard (SDDS) initiative which was launched by the International Monetary Fund (IMF) in 1996 to enhance the availability of timely and comprehensive macroeconomic and financial data based on best dissemination practices, facilitating the pursuit of sound macroeconomic policies. By joining this initiative, governments signal their willingness to be transparent in providing data in the public domain. However, almost two decades into the SDDS initiative, the question of whether the SDDS program served its purpose remains unexplored. We fill this gap in the literature by providing first quantitative evidence on the effects of the SDDS data transparency initiative. In order to do so, we rely on a new and unique Data Transparency Index computed by Hollyer et al. (2014) that measures the governments' ability to collect and disseminate aggregate economic data using a Bayesian item response algorithm model which treats transparency as a latent predictor of the reporting (absence) on 240 variables collected from the World Bank's World Development Indicators. Using panel data on 120 countries during the 1996-2010 period (15 years), we find that countries which comply with the SDDS initiative witness an increase in the data transparency index after controlling for self-section bias. We also find that these results are upheld when controlling for self-section bias. Our results also remain robust to excluding developed countries (i.e. high income OECD countries) from the sample, and also to using the instrumental variable approach and other alternative estimation techniques.

Our results highlight two key policy implications. First, indeed such transparency promoting initiatives do work. Skeptics have argued that such initiatives may not promote transparency. However, our results show that they actually do work. In fact, public dissemination of more accurate and timely economic and financial data in the wake of various financial crises has become an important macroeconomic tool to manage sound economic 
policies. Second, previous research has documented that investors do react to transparency (both data and governance). If so, cash strapped developing countries often dependent on short-term (and long-term) capital inflows to finance their balance of payment accounts could significantly benefit from an improvement in data transparency driven by complying with transparency promoting SDDS initiatives. By complying with the program and disclosing data, governments can signal their willingness to be transparent in providing macroeconomic and financial data to investors and thereby reduce the cost of accessing information. 


\section{References}

Achen, Christopher H. (2000) Why Lagged Dependent Variables can suppress the explanatory power of other independent variables, presented at the annual meeting of the political methodology, Los Angeles.

Arellano, M., and Bover, O., (1995) Another look at the Instrumental-Variable Estimation of Error-Components Models, Journal of Econometrics 68: 29-51.

Arellano, M., and Bond S., (1991) Some Tests of Specification for Panel Data: Monte Carlo Evidence and Application to Employment Equations, Review of Economic Studies 58(2): 277-297.

Brennan, Michael J., H. Henry Cao, Norman Strong, and Xinzhong Xu (2005) The dynamics of international equity market expectations, Journal of Financial Economics 77: 257 288.

Banerjee, A., (1992) A Simple Model of Herd Behavior, Quarterly Journal of Economics 107: 797-817.

Barro, Robert and Jong-Wha Lee (2005) IMF Programs: Who Is Chosen and What Are the Effects, Journal of Monetary Economics 52(7): 1245-1269.

Berliner, Daniel (2015) Competition and Compliance: Local Government Compliance with South Africa's Promotion of Access to Information Act, unpublished manuscript.

Berliner, Daniel and Aaron Erlich (2015, forthcoming) Competing for Transparency: Political Competition and Institutional Reform in Mexican States, American Political Science Review.

Berliner, Daniel (2014) The Political Origins of Transparency, The Journal of Politics 76(2): 479-491

Berliner, Daniel (2013) Follow your Neighbor? Regional Emulation and the Design of Transparency Policies, KFG Working Papers Series.

Berliner, Daniel (2012) Information Asymmetries and Information Laws: Freedom of Information Laws and Foreign Direct Investment, unpublished manuscript.

Bikhchandani, Sushil and Sunil Sharma (2000) Herd Behaviour in Financial Markets, IMF Staff Papers 47: 279-310.

Brennan, Michael J. and H. Henry Cao (1997) International portfolio investment flows, Journal of Finance 52: 1851-1880.

Bikhchandani, S., Hirshleifer, D., Welch, I., (1992) A Theory of Fads, Fashion, Custom, and Cultural Change as Information Cascades, Journal of Political Economy 100: 9921020 .

Boockmann, B., and Axel Dreher (2003) The Contribution of the IMF and the World Bank to Economic Freedom, European Journal of Political Economy, 19(3): 633-649.

Bound, J., Jaeger, D., Baker, R., 1995. Problems with instrumental variables estimation when the correlation between the instruments and the endogenous explanatory variable is weak, Journal of American Statistical Association 90: 443-450

Brennan, Michael J. and H. Henry Cao (1997) International portfolio investment flows, Journal of Finance 52: 1851-1880.

Blundell, R. and Bond, S., (1998) Initial Conditions and Moment Restrictions in Dynamic Panel Data Models, Journal of Econometrics 87(1): 115-143.

Bussell, Jennifer (2011) Explaining Cross-National Variation in Government Adoption of New Technologies, International Studies Quarterly 55: 267-280

Bussell, Jennifer (2010) Why Get Technical? Corruption and the Politics of Public Service Reform in the Indian States, Comparative Political Studies 43(10): 1230-1257

Cady, John (2005) Does SDDS Subscription Reduce Borrowing Costs for Emerging Market Economies? IMF Staff Papers 52(3): 503-17. 
Chordia, T., and L. Shivakumar (2006) Earnings and Price Momentum, Journal of Financial Economics 80(3): 627-656.

Core, John E. (2001) A Review of the Empirical Disclosure Literature: Discussion, Journal of Accounting and Economics 31: 441-456.

Costa, Samia Tavares (2013) Do Freedom of Information Laws Decrease Corruption? Journal of Law, Economics, and Organization 29(6): 1317-1343.

Cragg, John G, and S. G. Donald (1993) Testing Identifiability and Specification in Instrumental Variable Models, Econometric Theory 9: 222-240.

Diamond, Douglas W. and Robert E. Verrecchia (1991) Disclosure, Liquidity, and the Cost of Capital, Journal of Finance XLVI: 1325-59.

Drabek, Zdenek and Warren Payne (2001) The Impact of Transparency on FDI, staff working paper ERAD-99-02, WTO: Geneva.

Dreher, Axel, and Jan-Egbert Sturm (2012) Do the IMF and the World Bank influence voting in the UN General Assembly? Public Choice 151(1): 363-397.

Dreher, Axel (2006) IMF and Economic Growth: The Effects of Programs, Loans, and Compliance with Conditionality, World Development 34(5): 769-788

Easley, D., and M. O’Hara (2004) Information and the Cost of Capital, Journal of Finance 59: 1553-83.

Eichengreen, B. and D. Leblang (2008) Democracy and Globalization, Economics and Politics 20(3): 289-334.

Fratzscher, Marcel and Julien Reynaud (2011) IMF Surveillance and Financial Markets--A Political Economy Analysis, European Journal of Political Economy 27(3): 405-422.

Frenkel, Michael and Lukas Menkhoff (2004) Are Foreign Institutional Investors Good for Emerging Markets? The World Economy 27(8): 1275-1293.

Gassebner, Martin, Gaston, Noel, Lamla, Micheal, 2011. The inverse domino effect: are economic reforms contagious? International Economic Review 52(1): 183-200.

Gehrig, Thomas (1993) An information based explanation of the domestic bias in international equity investment, The Scandinavian Journal of Economics 95: 97-109.

Gelos, R. Gaston and Shang-Jin Wei (2002) Transparency and International Investor Behavior, NBER Working Paper No. 9260, NBER: Massachusetts.

Gelos, R. Gaston and Shang-Jin Wei (2005) Transparency and international portfolio holdings, Journal of Finance 60: 2987-3020.

Glennerster, Rachel and Shin, Yongseok (2007) Does Transparency Pay? IMF Staff Papers 55(1): 183-209.

Graham, Benjamin A. T. and Johnston, Noel P. and Kingsley, Allison (2014) The Capital Effects of Information Voids in Emerging Markets, unpublished manuscript, Available at SSRN: http://ssrn.com/abstract=2533651

Graham, Benjamin A. T. and Johnston, Noel P. and Kingsley, Allison (2013) Information, Political Risk, and the Competitive Advantage of Banks, unpublished manuscript.

Hahn, Jinyong, and Jerry Hausman (2002) A New Specification Test for the Validity of Instrumental Variables, Econometrica 70(1):163-189.

Hahn, Jinyong, and Jerry Hausman (2003) Weak Instruments: Diagnosis and Cures in Empirical Econometrics, American Economic Review 93(2):118-125.

Hashimoto, Yuko and Konstantin Wacker (2012) The Role of Risk and Information for International Capital Flows: New Evidence from the SDDS, IMF Working paper WP/12/242, International Monetary Fund: Washington D.C

Hausman, Jerry A. (1978) Specification Tests in Econometrics, Econometrica 46(6): 12511271

Heckman, J. J. (1979) Sample selection bias as a specification error, Econometrica 47(1): 153-161. 
Hoekman, Bernard and Kamal Saggi (1999) Multilateral disciplines for investment-related policies, Policy Research Working Paper Series 2138, The World Bank.

Hollyer, James R., Peter B. Rosendorff and James R. Vreeland (2015, Forthcoming) Transparency, Protest and Autocratic Instability, American Political Science Review.

Hollyer, James R., Peter B. Rosendorff, and James R. Vreeland (2014) Measuring Transparency, Political Analysis 22(1): 1-22

Hollyer, James R., Peter B. Rosendorff, and James R. Vreeland (2011) Democracy and Transparency, The Journal of Politics 73(4): 1191-1205

International Monetary Fund (2001) IMF Survey Supplement 30, September, International Monetary Fund: Washington D.C., 7-8.

International Monetary Fund (2001) Transparency, Policy Brief 01/05, IMF: Washington D.C. Accessed from: http://www.imf.org/external/np/exr/ib/2001/042601b.htm

Jakobsen, Jo and Indra de Soysa (2006) Do Foreign Investors punish Democracy? Theory and Empirics, 1984-2001, Kyklos 55(3): 383-410.

Kleibergen, F., and R. Paap (2006) Generalized reduced rank tests using the singular value decomposition, Journal of Econometrics 127: 97-126

Laeven, Luc, and Fabian Valencia (2008) Systemic Banking Crises: A New Database, IMF Working Papers, IMF: Washington D.C.

Laeven, Luc and Fabian Valencia (2013) Systemic Banking Crises Database, IMF Economic Review 61: 225-270.

Lancaster, Tony (2000) The Incidental Parameter Problem Since 1948, Journal of Econometrics 95: 391-413.

Marchesi, S., (2003) Adoption of an IMF Program and Debt Rescheduling. An empirical analysis, Journal of Development Economics 70(2): 403-423.

Marchesi, S., Thomas, J., (1999) IMF conditionality as a screening device, The Economic Journal 109: 111-125.

Marshall, M. G., and Jaggers, K., (2002) Polity IV Project: Political Regime Characteristics and Transitions, 1800-2000, College Park: University of Maryland.

Morris, S. and Shin, H. S. (2002) Social Value of Public Information, The American Economic Review 92(5): 1521-34.

Nickell, Stephen (1981) Biases in Dynamic Models with Fixed Effects, Econometrica 49(6): 1417-1426

Potrafke, Niklas (2012) Islam and democracy, Public Choice 151(1-2): 185-192.

Roodman, D., (2006) How to do xtabond2: An introduction to "difference" and "system" GMM in Stata, Centre for Global Development Working paper No. 103.

Sahin, Abdulhadi (2012) How Useful are the IMF Forecasts for Incumbent Governments? presented at the American Political Science Association Annual Meeting: New Orleans.

SDDS Guide (2007) The Special Data Dissemination Standard: Guide for Subscribers and Users, IMF: Washington D.C., accessed on $13^{\text {th }}$ January 2013, from: http://www.imf.org/external/pubs/ft/sdds/guide/2007/eng/sddsguide.pdf

SDDS program (2013) Special Data Dissemination Standard, IMF: Washington D.C., available at: http://dsbb.imf.org/Pages/SDDS/Home.aspx

Simmons, B.A., Elkins, Z., (2004) The globalization of liberalization: policy diffusion in the international political economy, American Political Science Review 98(1): 171-189.

Staiger, D., Stock, J.H., (1997) Instrumental variables regression with weak instruments, Econometrica 65: 557-586.

Stiglitz, J.E., (2000) The contributions of the economics of information to twentieth century economics, Quarterly Journal of Economics 115(4): 1441-1478. 
Stock, J., J. Wright, and M. Yogo (2002) A survey of weak instruments and weak identification in generalized method of moments, Journal of Business and Economic Statistics 20: 518-529.

Stone, Randall W. (2004) The Political Economy of IMF Lending in Africa, American Political Science Review 98: 577-592.

Strezhnev, Anton and Erik Voeten (2012) United Nations General Assembly Voting Data, Available at: http://hdl.handle.net/1902.1/12379.

Thacker, Strom C. (1999) The High Politics of IMF Lending, World Politics 52: 38-75.

Tong, Hui (2007) Disclosure standards and market efficiency: Evidence from analysts forecasts, Journal of International Economics 72(1): 222-41

UNCTADStat (2014) UNCTAD Statistics: New York, accessed from: http://unctadstat.unctad.org/ReportFolders/reportFolders.aspx

Vadlamannati, Krishna Chaitanya (2015, forthcoming) Fighting Corruption or Elections? The Politics of Anti-corruption Policies in India: A Subnational Study, Journal of Comparative Economics.

Vadlamannati, Krishna Chaitanya and Indra de Soysa (2015) Do Rulers of Natural Resource Wealth Welcome Transparency? An Empirical Analysis of Institutional Change, 1980-2012, Working paper, NTNU: Trondheim

Vadlamannati, Krishna Chaitanya and Arusha Cooray (2014) Transparency Pays: Evaluating the Effects of Freedom of Information Laws on Government Corruption, unpublished manuscript.

Vadlamannati, Krishna Chaitanya (2012) Impact of Political Risk on FDI Revisited - An Aggregated Firm-Level Analysis, International Interactions 38(1): 111-139

Voeten, Erik (2000) Clashes in the Assembly, International Organization 54(2): 185-215.

Voeten, Erik (2004) Resisting the Lonely Superpower: Responses of States in the UN to U.S. Dominance, The Journal of Politics 66(3): 729-54.

Williams, A. (2014) A global index of information transparency and accountability, Journal of Comparative Economics, http://dx.doi.org/10.1016/j.jce.2014.10.004

Williams, A., 2009. On the release of information by governments: causes and consequences, Journal of Development Economics 89(1): 124-138

Windmeijer, F. (2005) A Finite Sample Correction for the Variance of Linear Efficient TwoStep GMM Estimators, Journal of Econometrics 126: 25-51.

Wooldridge, Jeffrey (2002) Econometric Analysis of Cross Section and Panel Data, MIT Press.

World Bank (2014) World Development Indicators, The World Bank: Washington D.C. 
Table 1: Impact of SDDS compliance on Data transparency (Global sample)

\begin{tabular}{|c|c|c|c|c|c|c|}
\hline & $\begin{array}{c}\text { (1) } \\
\text { DT index }\end{array}$ & $\begin{array}{c}(2) \\
\text { DT index }\end{array}$ & $\begin{array}{c}(3) \\
\text { DT index }\end{array}$ & $\begin{array}{c}(4) \\
\text { DT index }\end{array}$ & $\begin{array}{c}(5) \\
\text { DT index }\end{array}$ & $\begin{array}{c}(6) \\
\text { DT index }\end{array}$ \\
\hline \multirow[t]{2}{*}{ SDDS Compliance } & $0.899 * * *$ & $0.863^{* * *}$ & $0.830^{* * *}$ & $0.422^{* * *}$ & $0.415^{* * *}$ & $0.394^{* * *}$ \\
\hline & $(0.109)$ & $(0.108)$ & $(0.110)$ & $(0.0667)$ & $(0.0663)$ & $(0.0665)$ \\
\hline \multirow[t]{2}{*}{ Per capita GDP (log) } & & $0.802^{* * *}$ & $0.783^{* * *}$ & & $0.835^{* * *}$ & $0.823^{* * *}$ \\
\hline & & $(0.169)$ & $(0.169)$ & & $(0.167)$ & $(0.167)$ \\
\hline \multirow[t]{2}{*}{ Democracy dummy } & & $0.309 * * *$ & $0.300 * * *$ & & $0.332 * * *$ & $0.320 * * *$ \\
\hline & & $(0.0754)$ & $(0.0753)$ & & $(0.0747)$ & $(0.0746)$ \\
\hline \multirow[t]{2}{*}{ Autocracy dummy } & & 0.0213 & 0.0141 & & 0.0803 & 0.0651 \\
\hline & & $(0.104)$ & $(0.104)$ & & $(0.102)$ & $(0.101)$ \\
\hline \multirow[t]{2}{*}{ Economic Crises Dummy } & & & -0.116 & & & -0.0726 \\
\hline & & & $(0.0914)$ & & & $(0.0879)$ \\
\hline \multirow[t]{2}{*}{ Natural Resource Rents/GDP } & & & $-0.00766^{* *}$ & & & $-0.0106^{* * *}$ \\
\hline & & & $(0.00341)$ & & & $(0.00328)$ \\
\hline \multirow[t]{2}{*}{ Trade/GDP } & & & 0.00144 & & & 0.000583 \\
\hline & & & $(0.00144)$ & & & $(0.00142)$ \\
\hline \multirow[t]{2}{*}{ Constant } & $0.817^{* * *}$ & $-5.441^{* * *}$ & $-5.362^{* * *}$ & $0.931^{* * *}$ & $-5.606^{* * *}$ & $-5.522^{* * *}$ \\
\hline & $(0.178)$ & $(1.297)$ & $(1.299)$ & $(0.184)$ & $(1.283)$ & $(1.285)$ \\
\hline \multicolumn{7}{|c|}{ SDDS comply SDDS comply SDDS comply } \\
\hline \multirow[t]{2}{*}{ Per capita GDP (log) } & $0.704^{* * *}$ & $0.704^{* * *}$ & $0.704^{* * *}$ & & & \\
\hline & $(0.0591)$ & $(0.0591)$ & $(0.0591)$ & & & \\
\hline \multirow[t]{2}{*}{ Democracy dummy } & 0.146 & 0.146 & 0.146 & & & \\
\hline & $(0.129)$ & $(0.129)$ & $(0.129)$ & & & \\
\hline \multirow[t]{2}{*}{ Autocracy dummy } & $-1.261^{* * *}$ & $-1.261^{* * *}$ & $-1.261^{* * *}$ & & & \\
\hline & $(0.230)$ & $(0.230)$ & $(0.230)$ & & & \\
\hline \multirow[t]{2}{*}{ Trade/GDP } & $-0.00303^{* * *}$ & $-0.00303^{* * *}$ & $-0.00303^{* * *}$ & & & \\
\hline & $(0.000988)$ & $(0.000988)$ & $(0.000988)$ & & & \\
\hline \multirow[t]{2}{*}{ Economic Crises Dummy } & -0.0617 & -0.0617 & -0.0617 & & & \\
\hline & $(0.337)$ & $(0.337)$ & $(0.337)$ & & & \\
\hline \multirow[t]{2}{*}{ IMF Program Participation } & -0.0806 & -0.0806 & -0.0806 & & & \\
\hline & $(0.177)$ & $(0.177)$ & $(0.177)$ & & & \\
\hline \multirow[t]{2}{*}{ Natural Resource Rents/GDP } & $-0.0326^{* * *}$ & $-0.0326^{* * *}$ & $-0.0326 * * *$ & & & \\
\hline & $(0.00470)$ & $(0.00470)$ & $(0.00470)$ & & & \\
\hline \multirow[t]{2}{*}{ Corruption index } & -0.0921 & -0.0921 & -0.0921 & & & \\
\hline & $(0.0791)$ & $(0.0791)$ & $(0.0791)$ & & & \\
\hline \multirow[t]{2}{*}{ Constant } & -12.27 & -12.27 & -12.27 & & & \\
\hline & $(133.9)$ & $(133.9)$ & $(133.9)$ & & & \\
\hline Estimator & Treatreg & Treatreg & Treatreg & FGLS & FGLS & FGLS \\
\hline Wald chi2 & $20060.3^{* * *}$ & $20857.1^{* * *}$ & $21061.2^{* * *}$ & $22113.9^{* * *}$ & $22714.4^{* * *}$ & $22863.6^{* * *}$ \\
\hline Sample of countries & Global & Global & Global & Global & Global & Global \\
\hline Time Fixed Effects & Yes & Yes & Yes & Yes & Yes & Yes \\
\hline Country Fixed Effects & No (Yes) & No (Yes) & No (Yes) & Yes & Yes & Yes \\
\hline Number of Countries & 120 & 120 & 120 & 120 & 120 & 120 \\
\hline Number of Observations & 1800 & 1800 & 1800 & 1800 & 1800 & 1800 \\
\hline
\end{tabular}

Notes: Country fixed effects (for the treatment regression only for the linear estimation) and year dummies are included and robust standard errors in parenthesis. ${ }^{* * *} \mathrm{p}<0.01,{ }^{* *} \mathrm{p}<0.05,{ }^{*} \mathrm{p}<0.1$ 
Table 2: Impact of SDDS compliance on Data transparency (Non-OECD sample)

\begin{tabular}{|c|c|c|c|c|c|c|}
\hline & $\begin{array}{c}\text { (1) } \\
\text { DT index }\end{array}$ & $\begin{array}{c}(2) \\
\text { DT index }\end{array}$ & $\begin{array}{c}(3) \\
\text { DT index }\end{array}$ & $\begin{array}{c}(4) \\
\text { DT index }\end{array}$ & $\begin{array}{c}(5) \\
\text { DT index }\end{array}$ & $\begin{array}{c}(6) \\
\text { DT index }\end{array}$ \\
\hline \multirow[t]{2}{*}{ SDDS Compliance } & $0.823^{* * *}$ & $0.784^{* * *}$ & $0.744^{* * *}$ & $0.377^{* * *}$ & $0.367^{* * *}$ & $0.343^{* * *}$ \\
\hline & $(0.0832)$ & $(0.0842)$ & $(0.0859)$ & $(0.0676)$ & $(0.0671)$ & $(0.0676)$ \\
\hline \multirow[t]{2}{*}{ Per capita GDP (log) } & & $0.538^{* * *}$ & $0.521^{* * *}$ & & $0.573^{* * *}$ & $0.554^{* * *}$ \\
\hline & & $(0.149)$ & $(0.148)$ & & $(0.146)$ & $(0.146)$ \\
\hline \multirow[t]{2}{*}{ Democracy dummy } & & $0.289^{* * *}$ & $0.281^{* * *}$ & & $0.321^{* * *}$ & $0.307^{* * *}$ \\
\hline & & $(0.0640)$ & $(0.0638)$ & & $(0.0632)$ & $(0.0630)$ \\
\hline \multirow[t]{2}{*}{ Autocracy dummy } & & 0.0930 & 0.0831 & & 0.113 & 0.0995 \\
\hline & & $(0.0882)$ & $(0.0878)$ & & $(0.0861)$ & $(0.0858)$ \\
\hline \multirow[t]{2}{*}{ Economic Crises Dummy } & & & -0.124 & & & -0.105 \\
\hline & & & $(0.0884)$ & & & $(0.0852)$ \\
\hline \multirow[t]{2}{*}{ Natural Resource Rents/GDP } & & & $-0.00742^{* *}$ & & & $-0.00967^{* * *}$ \\
\hline & & & $(0.00291)$ & & & $(0.00282)$ \\
\hline \multirow[t]{2}{*}{ Trade/GDP } & & & 0.000634 & & & -0.000157 \\
\hline & & & $(0.00125)$ & & & $(0.00123)$ \\
\hline \multirow[t]{3}{*}{ Constant } & $0.766^{* * *}$ & $-3.497^{* * *}$ & $-3.374^{* * *}$ & $0.899 * * *$ & $-3.645^{* * *}$ & $-3.458^{* * *}$ \\
\hline & $(0.151)$ & $(1.145)$ & $(1.143)$ & $(0.157)$ & $(1.124)$ & $(1.124)$ \\
\hline & SDDS comply & SDDS comply & SDDS comply & & & \\
\hline \multirow[t]{2}{*}{ Per capita GDP $(\log )$} & $0.690^{* * *}$ & $0.707^{* * *}$ & $0.710^{* * *}$ & & & \\
\hline & $(0.0619)$ & $(0.0621)$ & $(0.0621)$ & & & \\
\hline \multirow[t]{2}{*}{ Democracy dummy } & $0.244^{* *}$ & 0.128 & 0.137 & & & \\
\hline & $(0.122)$ & $(0.126)$ & $(0.126)$ & & & \\
\hline \multirow[t]{2}{*}{ Autocracy dummy } & $-1.373^{* * *}$ & $-1.475^{* * *}$ & $-1.479^{* * *}$ & & & \\
\hline & $(0.238)$ & $(0.240)$ & $(0.240)$ & & & \\
\hline \multirow[t]{2}{*}{ Trade/GDP } & $-0.00469^{* * *}$ & $-0.00494^{* * *}$ & $-0.00499^{* * *}$ & & & \\
\hline & $(0.00111)$ & $(0.00113)$ & $(0.00113)$ & & & \\
\hline \multirow[t]{2}{*}{ Economic Crises Dummy } & -0.196 & -0.184 & -0.0786 & & & \\
\hline & $(0.377)$ & $(0.377)$ & $(0.390)$ & & & \\
\hline \multirow[t]{2}{*}{ IMF Program Participation } & -0.0269 & -0.0246 & -0.0318 & & & \\
\hline & $(0.158)$ & $(0.160)$ & $(0.162)$ & & & \\
\hline \multirow[t]{2}{*}{ Natural Resource Rents/GDP } & $-0.0368^{* * *}$ & $-0.0377^{* * *}$ & $-0.0362^{* * *}$ & & & \\
\hline & $(0.00476)$ & $(0.00482)$ & $(0.00487)$ & & & \\
\hline \multirow[t]{2}{*}{ Corruption index } & 0.111 & 0.107 & 0.115 & & & \\
\hline & $(0.0973)$ & $(0.0974)$ & $(0.0976)$ & & & \\
\hline \multirow[t]{2}{*}{ Constant } & -12.73 & -13.10 & -12.71 & & & \\
\hline & $(378.9)$ & $(1,031)$ & $(240.5)$ & & & \\
\hline Estimator & Treatreg & Treatreg & Treatreg & FGLS & FGLS & FGLS \\
\hline Wald chi2 & $17653.0^{* * *}$ & $17955.4^{* \star *}$ & $18079.8^{* * *}$ & $20090.7^{* * *}$ & $20691.4^{* * *}$ & $20898.1^{* * *}$ \\
\hline Sample of countries & Non-OECD & Non-OECD & Non-OECD & Non-OECD & Non-OECD & Non-OECD \\
\hline Time Fixed Effects & Yes & Yes & Yes & Yes & Yes & Yes \\
\hline Country Fixed Effects & No (Yes) & No (Yes) & No (Yes) & Yes & Yes & Yes \\
\hline Number of Countries & 100 & 100 & 100 & 100 & 100 & 100 \\
\hline Number of Observations & 1500 & 1500 & 1500 & 1500 & 1500 & 1500 \\
\hline
\end{tabular}

Notes: Country fixed effects (for the treatment regression only for the linear estimation) and year dummies are included and robust standard errors in parenthesis. ${ }^{* * *} \mathrm{p}<0.01,{ }^{* *} \mathrm{p}<0.05,{ }^{*} \mathrm{p}<0.1$ 
Table 3: Impact of SDDS compliance on Data transparency (control for other key variables)

\begin{tabular}{|c|c|c|c|c|}
\hline & $\begin{array}{c}(1) \\
\text { DT index }\end{array}$ & $\begin{array}{c}(2) \\
\text { DT index }\end{array}$ & $\begin{array}{c}(3) \\
\text { DT index }\end{array}$ & $\begin{array}{c}\text { (4) } \\
\text { DT index }\end{array}$ \\
\hline SDDS Compliance & $\begin{array}{c}0.862^{* * *} \\
(0.112)\end{array}$ & $\begin{array}{c}0.778 * * * \\
(0.120)\end{array}$ & $\begin{array}{l}0.397^{* * *} \\
(0.0672)\end{array}$ & $\begin{array}{l}0.348^{* * *} \\
(0.0709)\end{array}$ \\
\hline Per capita GDP (log) & $\begin{array}{c}0.795^{* * *} \\
(0.181)\end{array}$ & $\begin{array}{c}0.720^{* * *} \\
(0.184)\end{array}$ & $\begin{array}{c}0.844^{* * *} \\
(0.180)\end{array}$ & $\begin{array}{c}0.743^{* * *} \\
(0.183)\end{array}$ \\
\hline Democracy dummy & $\begin{array}{l}0.247^{* * *} \\
(0.0774)\end{array}$ & $\begin{array}{l}0.326^{* * *} \\
(0.0835)\end{array}$ & $\begin{array}{l}0.270 * * * \\
(0.0766)\end{array}$ & $\begin{array}{l}0.341^{* * *} \\
(0.0830)\end{array}$ \\
\hline Autocracy dummy & $\begin{array}{c}-0.0157 \\
(0.110)\end{array}$ & $\begin{array}{l}0.0917 \\
(0.123)\end{array}$ & $\begin{array}{l}0.0445 \\
(0.106)\end{array}$ & $\begin{array}{c}0.139 \\
(0.120)\end{array}$ \\
\hline Economic Crises Dummy & $\begin{array}{c}-0.122 \\
(0.0926)\end{array}$ & $\begin{array}{c}-0.122 \\
(0.0952)\end{array}$ & $\begin{array}{l}-0.0753 \\
(0.0886)\end{array}$ & $\begin{array}{l}-0.0857 \\
(0.0919)\end{array}$ \\
\hline Natural Resource Rents/GDP & $\begin{array}{l}-0.00621^{*} \\
(0.00356)\end{array}$ & $\begin{array}{c}-0.0110^{* * *} \\
(0.00386)\end{array}$ & $\begin{array}{c}-0.00974^{* * *} \\
(0.00341)\end{array}$ & $\begin{array}{c}-0.0147^{* * *} \\
(0.00371)\end{array}$ \\
\hline Trade/GDP & $\begin{array}{l}0.000281 \\
(0.00154)\end{array}$ & $\begin{array}{l}0.000761 \\
(0.00156)\end{array}$ & $\begin{array}{r}-0.000513 \\
(0.00152)\end{array}$ & $\begin{array}{l}7.41 \mathrm{e}-05 \\
(0.00155)\end{array}$ \\
\hline Economic Reforms index & $\begin{array}{c}0.00406 \\
(0.00460)\end{array}$ & & $\begin{array}{c}0.00331 \\
(0.00460)\end{array}$ & \\
\hline Transparency in System & & $\begin{array}{l}0.00529 \\
(0.0152)\end{array}$ & & $\begin{array}{c}0.0175 \\
(0.0149)\end{array}$ \\
\hline Constant & $\begin{array}{c}-5.584^{* * *} \\
(1.364) \\
\end{array}$ & $\begin{array}{c}-4.912^{* * *} \\
(1.415) \\
\end{array}$ & $\begin{array}{c}-5.779 * * * \\
(1.351) \\
\end{array}$ & $\begin{array}{c}-5.018^{* * *} \\
(1.402)\end{array}$ \\
\hline & SDDS comply & SDDS comply & & \\
\hline Per capita GDP (log) & $\begin{array}{l}0.705^{* * *} \\
(0.0591)\end{array}$ & $\begin{array}{l}0.668^{* * *} \\
(0.0614)\end{array}$ & & \\
\hline Democracy dummy & $\begin{array}{c}0.132 \\
(0.130)\end{array}$ & $\begin{array}{c}0.123 \\
(0.134)\end{array}$ & & \\
\hline Autocracy dummy & $\begin{array}{c}-1.277^{* * *} \\
(0.230)\end{array}$ & $\begin{array}{c}-1.300^{* * *} \\
(0.234)\end{array}$ & & \\
\hline Trade/GDP & $\begin{array}{c}-0.00310^{* * *} \\
(0.000989)\end{array}$ & $\begin{array}{c}-0.00239^{* *} \\
(0.00104)\end{array}$ & & \\
\hline Economic Crises Dummy & $\begin{array}{c}-0.0635 \\
(0.336)\end{array}$ & $\begin{array}{r}-0.0975 \\
(0.337)\end{array}$ & & \\
\hline IMF Program Participation & $\begin{array}{r}-0.0845 \\
(0.177)\end{array}$ & $\begin{array}{r}-0.0975 \\
(0.337)\end{array}$ & & \\
\hline Natural Resource Rents/GDP & $\begin{array}{c}-0.0325^{* * *} \\
(0.00469)\end{array}$ & $\begin{array}{c}-0.0356^{* * *} \\
(0.00486)\end{array}$ & & \\
\hline Corruption index & $\begin{array}{l}-0.0952 \\
(0.0791)\end{array}$ & $\begin{array}{l}-0.0757 \\
(0.0808)\end{array}$ & & \\
\hline Constant & $\begin{array}{l}-12.27 \\
(136.3) \\
\end{array}$ & $\begin{array}{l}-11.94 \\
(140.9) \\
\end{array}$ & & \\
\hline Estimator & Treatreg & Treatreg & FGLS & FGLS \\
\hline Wald chi2 & $20462.1^{* * *}$ & $18147.6^{* * *}$ & $22342.4^{* * *}$ & $19478.4^{* * *}$ \\
\hline Time Fixed Effects & Yes & Yes & Yes & Yes \\
\hline Country Fixed Effects & No (Yes) & No (Yes) & No (Yes) & Yes \\
\hline Number of Countries & 120 & 109 & 120 & 109 \\
\hline Number of Observations & 1773 & 1635 & 1773 & 1635 \\
\hline
\end{tabular}

Notes: Country fixed effects (for the treatment regression only for the linear estimation) and year dummies are included and robust standard errors in parenthesis. ${ }^{* * *} \mathrm{p}<0.01,{ }^{* *} \mathrm{p}<0.05,{ }^{*} \mathrm{p}<0.1$ 
Table 4: Impact of SDDS compliance on Data transparency (2SLS-IV estimations)

\begin{tabular}{|c|c|c|c|c|}
\hline & $\begin{array}{c}\text { (1) } \\
\text { DT index }\end{array}$ & $\begin{array}{c}(2) \\
\text { DT index }\end{array}$ & $\begin{array}{c}(3) \\
\text { DT index }\end{array}$ & $\begin{array}{c}(4) \\
\text { DT index }\end{array}$ \\
\hline SDDS Compliance & $\begin{array}{c}1.213^{* * *} \\
(0.209)\end{array}$ & $\begin{array}{c}1.234^{* * *} \\
(0.209)\end{array}$ & $\begin{array}{c}2.089^{* * *} \\
(0.361)\end{array}$ & $\begin{array}{c}2.213^{* * *} \\
(0.383)\end{array}$ \\
\hline Per capita GDP (log) & & $\begin{array}{c}0.657^{* * *} \\
(0.174)\end{array}$ & & $\begin{array}{c}0.171 \\
(0.188)\end{array}$ \\
\hline Democracy dummy & & $\begin{array}{l}0.384^{\star * *} \\
(0.0655)\end{array}$ & & $\begin{array}{l}0.406^{* * *} \\
(0.0774)\end{array}$ \\
\hline Autocracy dummy & & $\begin{array}{l}0.0606 \\
(0.0768)\end{array}$ & & $\begin{array}{c}0.150 \\
(0.0911)\end{array}$ \\
\hline Economic Crises Dummy & & $\begin{array}{r}-0.0118 \\
(0.100)\end{array}$ & & $\begin{array}{c}0.198 \\
(0.137)\end{array}$ \\
\hline Natural Resource Rents/GDP & & $\begin{array}{c}-0.00696^{* *} \\
(0.00302)\end{array}$ & & $\begin{array}{l}-0.00475 \\
(0.00335)\end{array}$ \\
\hline Trade/GDP & & $\begin{array}{l}-5.47 e-06 \\
(0.00150)\end{array}$ & & $\begin{array}{l}-0.00198 \\
(0.00181)\end{array}$ \\
\hline Constant & $\begin{array}{c}1.133^{* * *} \\
(0.133)\end{array}$ & $\begin{array}{c}-4.059^{* * *} \\
(1.329) \\
\end{array}$ & $\begin{array}{c}1.222^{* * *} \\
(0.140) \\
\end{array}$ & $\begin{array}{l}-0.180 \\
(1.472) \\
\end{array}$ \\
\hline R-squared & 0.918 & 0.920 & 0.901 & 0.899 \\
\hline Estimator & 2SLS-IV & 2SLS-IV & 2SLS-IV & 2SLS-IV \\
\hline Sample of countries & Global & Global & Non-OECD & Non-OECD \\
\hline F-statistic (First-step) & $323.7^{* * *}$ & $285.6^{* * *}$ & $65.2^{* * *}$ & $55.9^{* * *}$ \\
\hline Cragg-Donald Wald F statistic & $261.1^{* * *}$ & $259.3^{* * *}$ & $82.4^{* * *}$ & $77.6^{* * *}$ \\
\hline Kleibergen-Paap rk F statistic & $323.7^{* * *}$ & $285.6^{* * *}$ & $65.2^{* * *}$ & $55.9^{* * *}$ \\
\hline Hansen J statistic (p-value) & 0.119 & 0.129 & 0.276 & 0.321 \\
\hline Time Fixed Effects & Yes & Yes & Yes & Yes \\
\hline Country Fixed Effects & Yes & Yes & Yes & Yes \\
\hline Number of Countries & 120 & 120 & 100 & 100 \\
\hline Number of Observations & 1778 & 1778 & 1498 & 1498 \\
\hline
\end{tabular}

Notes: Country fixed effects and year dummies are included and robust standard errors in parenthesis. ${ }^{* * *} \mathrm{p}<0.01,{ }^{* *} \mathrm{p}<0.05,{ }^{*} \mathrm{p}<0.1$ 
Figure 1: SDDS Program: Signing and Complying during 1996-2011 period

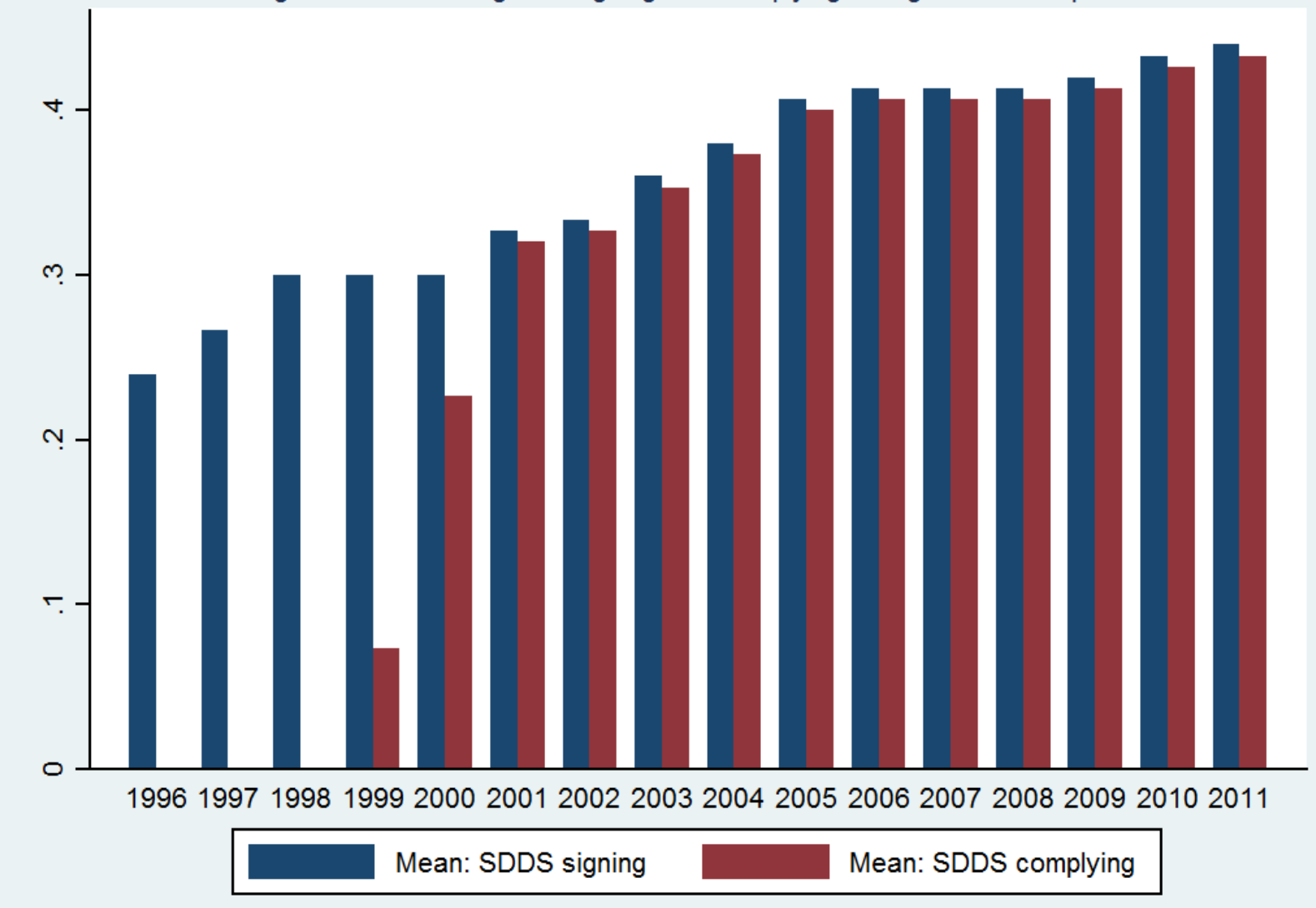

Figure 2: Hollyer et al. (2014) Data Transparency Index during 1980-2010 period

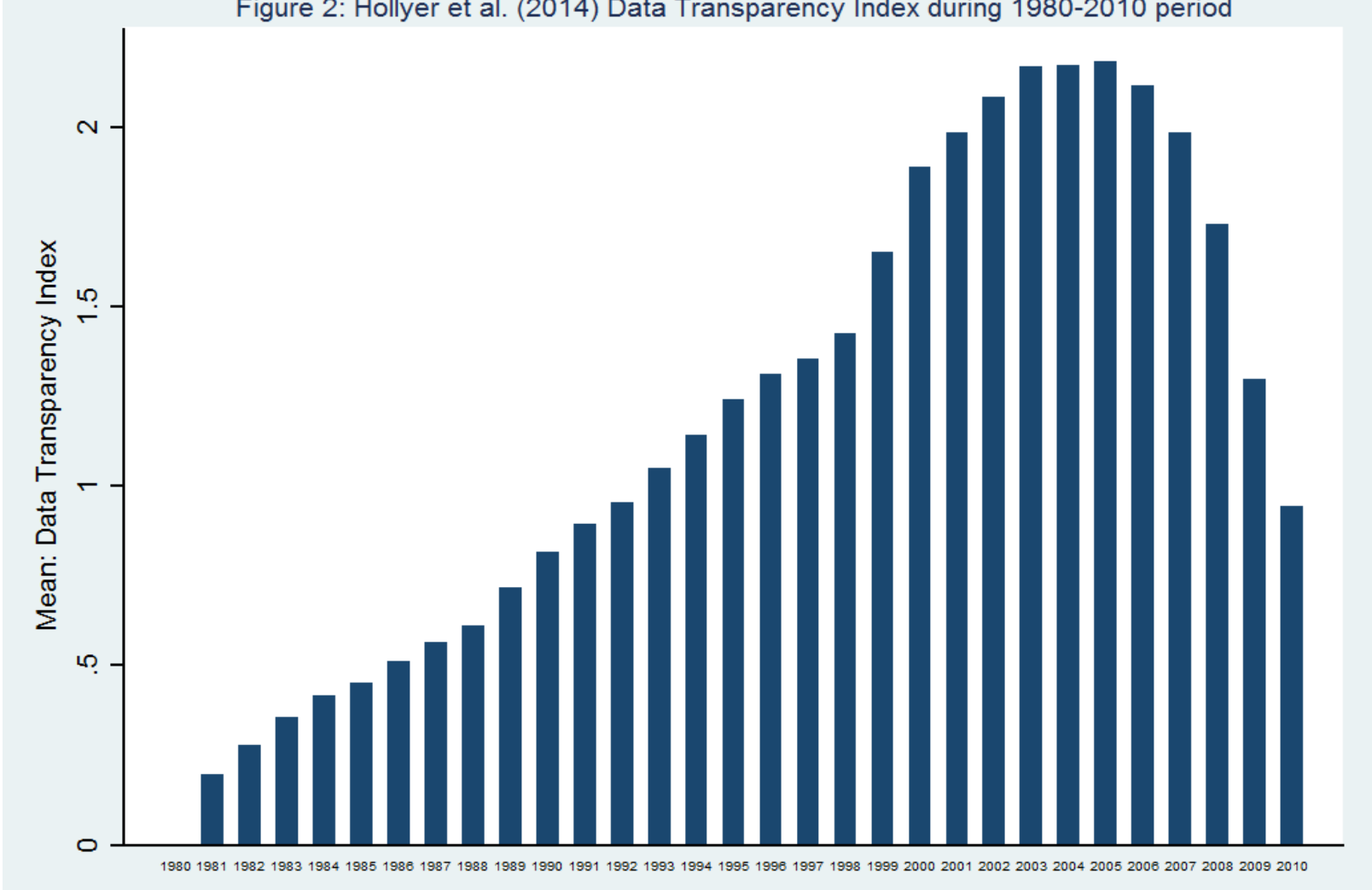


Figure 3: (Mean) Data Transparency Index - SDDS compliers vs. Non-members during 1996-2010 period

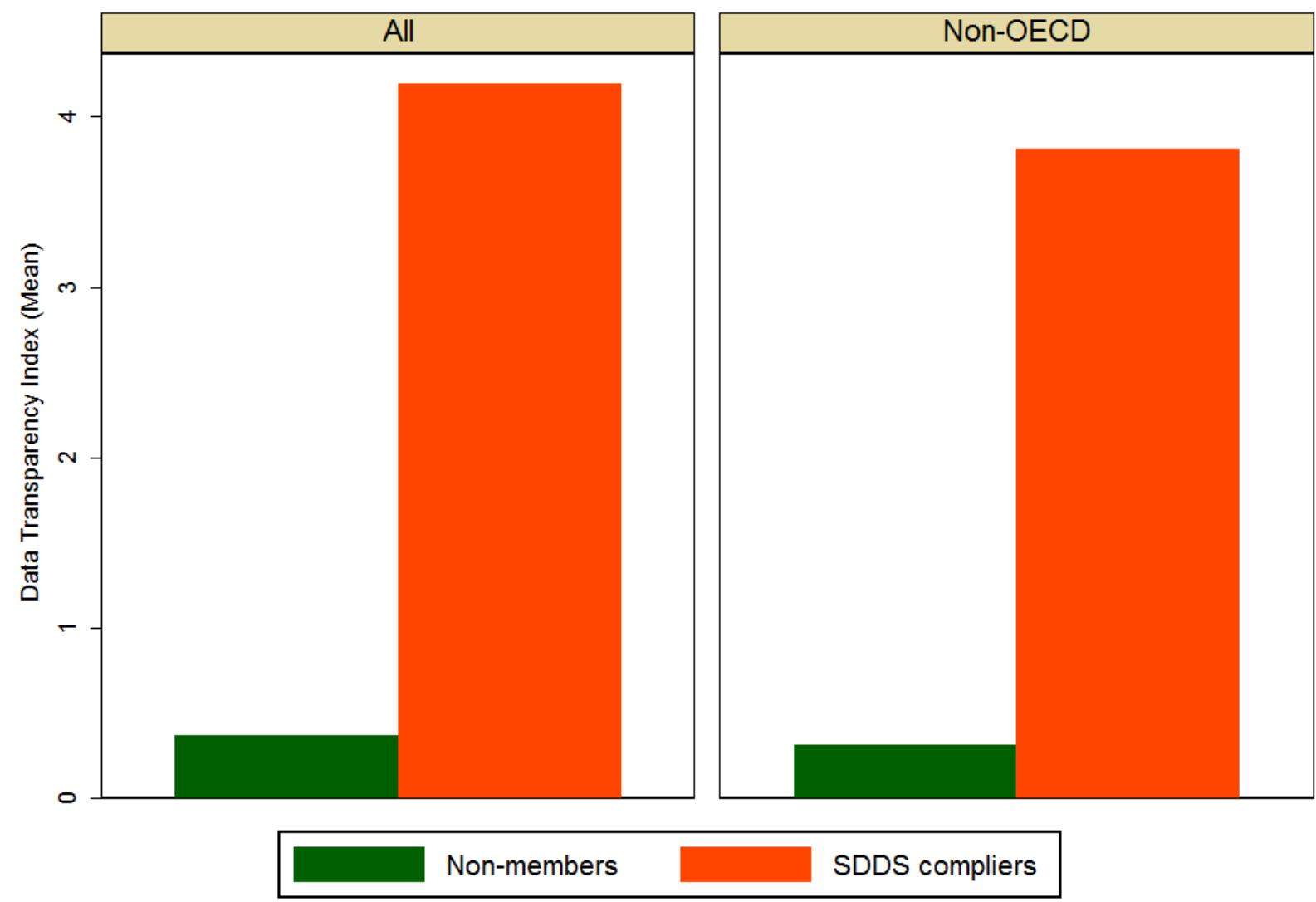




\section{Appendix}

Appendix 1: Countries under study

\begin{tabular}{|c|c|c|c|c|}
\hline Albania & Cote d Ivoire & Hungary & Moldova & Slovakia \\
\hline Algeria & Croatia & India & Mongolia & Slovenia \\
\hline Angola & Cuba & Indonesia & Morocco & South Africa \\
\hline Argentina & Cyprus & Iran & Mozambique & Spain \\
\hline Armenia & Czech Republic & Ireland & Myanmar & Sri Lanka \\
\hline Australia & Denmark & Israel & Namibia & Sudan \\
\hline Austria & Djibouti & Italy & Nepal & Sweden \\
\hline Azerbaijan & Dominican Republic & Jamaica & Netherlands & Switzerland \\
\hline Bahrain & Ecuador & Japan & New Zealand & Syria \\
\hline Bangladesh & Egypt & Jordan & Nicaragua & Taiwan \\
\hline Belarus & El Salvador & Kazakhstan & Niger & Tajikistan \\
\hline Belgium & Equatorial Guinea & Kenya & Nigeria & Tanzania \\
\hline Benin & Eritrea & Korea, Republic of & Norway & Thailand \\
\hline Bolivia & Estonia & Kuwait & Oman & Togo \\
\hline Botswana & Ethiopia & Kyrgyzstan & Pakistan & Trinidad \& Tobago \\
\hline Brazil & Fiji & Lao LDR & Panama & Tunisia \\
\hline Bulgaria & Finland & Latvia & Papua New Guinea & Turkey \\
\hline Burkina Faso & France & Lebanon & Paraguay & Turkmenistan \\
\hline Burundi & Gabon & Lesotho & Peru & Uganda \\
\hline Cambodia & Gambia & Liberia & Philippines & Ukraine \\
\hline Cameroon & Georgia & Libya & Poland & United Arab Emirates \\
\hline Canada & Germany & Lithuania & Portugal & United Kingdom \\
\hline Cape Verde & Ghana & Macedonia & Qatar & United States \\
\hline Central African Republic & Greece & Madagascar & Romania & Uruguay \\
\hline Chile & Guatemala & Malawi & Russian Federation & Uzbekistan \\
\hline China & Guinea & Malaysia & Rwanda & Venezuela \\
\hline Colombia & Guinea-Bissau & Mali & Saudi Arabia & Vietnam \\
\hline Congo Republic & Guyana & Mauritania & Senegal & Yemen \\
\hline Congo, Democratic Republic & Haiti & Mauritius & Sierra Leone & Zambia \\
\hline Costa Rica & Honduras & Mexico & Singapore & Zimbabwe \\
\hline
\end{tabular}


Appendix 2: SDDS Compliance information

\begin{tabular}{|c|c|c|}
\hline Country & Date of Subscription & Date whensubscription met \\
\hline Argentina & 16 August 1996 & 01 November 1999 \\
\hline Arm enia & 07 November 2003 & 07 November 2003 \\
\hline Australia & 19 April 1996 & 23 July 2001 \\
\hline Austria & 04 September 1996 & 05 July 2001 \\
\hline Belarus, Republic of & 22 Decem ber 2004 & 22 Decem ber 2004 \\
\hline Belgium & 06 June 1996 & 26 January 2001 \\
\hline Brazil & 14March2001 & 14March2001 \\
\hline Bulgaria & 01 Decem ber 2003 & 01 Decem ber 2003 \\
\hline Canada & 20 April1996 & 19 February 1999 \\
\hline Chile & 17 May 1996 & 30 March 2000 \\
\hline Colom bia & 31 May 1996 & 09 May 2000 \\
\hline Costa Rica & 28 November 2001 & 28 November 2001 \\
\hline Croatia & 20 May 1996 & 30 March2001 \\
\hline Cyprus & 01 Decem ber 2009 & 01 Decem ber 2009 \\
\hline CzechRepublic & 21 April1998 & 04 June 1999 \\
\hline Denm ark & 07 June 1996 & 01 September 2000 \\
\hline Ecuador & 27 March1998 & 14 July 2000 \\
\hline Egpt & 31 January 2005 & 31 January 2005 \\
\hline ElSalvador & 05 June 1998 & 12 October 1999 \\
\hline Estonia & 30 September 1998 & $30 \mathrm{March} 2000$ \\
\hline Finland & 03 June 1996 & 02 June 2000 \\
\hline France & 08 August 1996 & 27 April2001 \\
\hline Georgia & 17 May 2010 & 17 May 2010 \\
\hline Germany & 02 Decem ber 1996 & 23 March2000 \\
\hline Greece & 08 November 2002 & 08 November 2002 \\
\hline Hungary & 24May 1996 & 24. January 2000 \\
\hline Iceland & 21 June 1996 & 30 June 2004 \\
\hline India & 27 Decem ber 1996 & 14Decem ber 2001 \\
\hline Indonesia & 24September 1996 & 02 June 2000 \\
\hline Ireland & 26 June 1996 & 17 July 2001 \\
\hline Israel & 23 April1996 & 05 June 2000 \\
\hline Italy & 13 August 1996 & 14 April2000 \\
\hline Japan & 03 July 1996 & 09 June 2000 \\
\hline Jordan & 28 January 2010 & 28 January 2010 \\
\hline Kazakhstan & 24March2003 & $24 \mathrm{Mm}$ arch2003 \\
\hline Korea,South & 20 September 1996 & 01 November 1999 \\
\hline Kyrgyz Republic & 26 February 2004 & 26 February 2004 \\
\hline Latvia & 01 November 1996 & 28 September 1999 \\
\hline Lithuania & 30 May 1996 & 12 July 1999 \\
\hline Macedoria, FYR & 21 November 2011 & 21 November 2011 \\
\hline Malaysia & 21 August 1996 & 01 September 2000 \\
\hline Mauritius & 28 February 2012 & 28 February 2012 \\
\hline Mexico & 13 August 1996 & 29 June 2000 \\
\hline Moldow, Republic of & $02 \mathrm{May} 2006$ & 02 May 2006 \\
\hline Morocco & 15 Decem ber 2005 & 15 Decem ber 2005 \\
\hline Netherlands & 11 June 1996 & 26 Apri12000 \\
\hline Nonway & 18 June 1996 & 28 April2000 \\
\hline Peru & 07 August 1996 & 15 July 1999 \\
\hline Philippines & 05 August 1996 & 17 January 2001 \\
\hline Poland & 17 August 1996 & 02 March2000 \\
\hline Portugal & 11 September 1997 & 01 Decem ber 2000 \\
\hline Rom aria & 04 May 2005 & 04 May 2005 \\
\hline Russian Federation & 31 January 2005 & 31 January 2005 \\
\hline Singapore & 01 August 1996 & 30 January 2001 \\
\hline Slovak Republic & 10 September 1996 & 07 October 1999 \\
\hline Slovenia & 02 August 1996 & 07 July 2000 \\
\hline SouthAfrica & 02 August 1996 & 18 September 2000 \\
\hline Spain & 27 September 1996 & 21 Decem ber 2000 \\
\hline Sweden & 31 May 1996 & 29 June 2000 \\
\hline Switzerland & 11 June 1996 & 18 May 2001 \\
\hline Thailand & 09 August 1996 & 16 May 2000 \\
\hline Tunisia & 20 June 2001 & 20 June 2001 \\
\hline Turkey & 08 August 1996 & 20 July 2001 \\
\hline Ukraine & 10 January 2003 & 10 January 2003 \\
\hline UnitedKingdom & 16 August 1996 & 06 July 1999 \\
\hline UnitedStates & 06 May 1996 & 19 February 1999 \\
\hline Uruguay & 12 February 2004 & 12 February 2004 \\
\hline
\end{tabular}

Source: http://dsbb.imf.org/Pages/SDDS/DateOfSubscription.aspx 
Appendix 3: Descriptive Statistics

\begin{tabular}{lccccc}
\hline \multicolumn{1}{c}{ Variables } & Mean & Standard Deviation & Minimum & Maximum & Observations \\
\hline Data Transparency index & 1.929 & 2.444 & -2.954 & 9.981 & 1800 \\
SDDS Compliance & 0.285 & 0.452 & 0.000 & 1.000 & 2400 \\
Per capita GDP (log) & 7.917 & 1.640 & 4.411 & 11.119 & 2400 \\
Democracy dummy & 0.550 & 0.498 & 0.000 & 1.000 & 2400 \\
Autocracy dummy & 0.181 & 0.385 & 0.000 & 1.000 & 2400 \\
Trade/GDP & 83.582 & 44.590 & 14.933 & 460.471 & 2400 \\
Economic Crises dummy & 0.034 & 0.181 & 0.000 & 1.000 & 2400 \\
IMF Program Participation & 0.101 & 0.302 & 0.000 & 1.000 & 2400 \\
Natural resource rents/GDP & 11.208 & 15.739 & 0.000 & 94.640 & 2400 \\
Corruption index & -0.102 & 1.005 & -2.060 & 2.590 & 2400 \\
Economic Policy Reforms & 58.206 & 11.644 & 21.400 & 90.100 & 2359 \\
UNGA voting Alignment & 0.327 & 0.149 & 0.000 & 0.941 & 2361 \\
SDDS Compliance regional share & 25.050 & 27.942 & 0.000 & 90.625 & 2400 \\
\hline
\end{tabular}


Appendix 4: Data definition and sources

\begin{tabular}{|c|c|}
\hline Variables & Data definition and sources \\
\hline SDDS compliance & $\begin{array}{l}\text { Coded the value } 1 \text { if country } i \text { in year } t \text { complied with SDDS program and } 0 \\
\text { otherwise sourced from the SDDS division at the IMF. }\end{array}$ \\
\hline Data Transparency index & $\begin{array}{l}\text { Is a continuous measure ranging from }-10.9 \text { to }+10 \text { in which higher scores } \\
\text { denote greater disclosure of the government on } 240 \text { measures from the WDI } \\
\text { sourced from Hollyer, Rosendorff and Vreeland (2014) }\end{array}$ \\
\hline Per capita GDP (log) & GDP per head in 2000 US\$ constant prices sourced from UNCTAD (2014) \\
\hline Democracy & $\begin{array}{l}\text { Based on Polity IV index }(-10 \text { to }+10) \text { takes the value } 1 \text { if the Polity IV index is } \\
+5 \text { and above and } 0 \text { otherwise. }\end{array}$ \\
\hline Autocracy & $\begin{array}{l}\text { Based on Polity IV index }(-10 \text { to }+10) \text { takes the value } 1 \text { if the Polity IV index is } \\
-5 \text { and below and } 0 \text { otherwise. }\end{array}$ \\
\hline Economic Crises & $\begin{array}{l}\text { Coded the value } 1 \text { if country } i \text { in year } t \text { faced with either debt, currency and } \\
\text { banking crisis and } 0 \text { otherwise sourced from Laeven and Valencia (2013) }\end{array}$ \\
\hline Trade/GDP & $\begin{array}{l}\text { Sourced from the UNCTAD statistics (2014) wherein total imports and exports } \\
\text { are considered as a share of GDP. }\end{array}$ \\
\hline IMF Program Participation & $\begin{array}{l}\text { Coded the value } 1 \text { if country } i \text { in year } t \text { is under an IMF program sourced from } \\
\text { Dreher (2006) }\end{array}$ \\
\hline Natural resource rents/GDP & $\begin{array}{l}\text { Sourced from the World Bank's WDI (2014) which defines resource rents as } \\
\text { unit price minus the cost of production times the quantity produced. The total } \\
\text { resource rents value is considered as a share of GDP. }\end{array}$ \\
\hline $\begin{array}{l}\text { SDDS Compliance regional } \\
\text { share }\end{array}$ & $\begin{array}{l}\text { The share of country } i^{\text {th }} \text { neighboring countries in that geographic region that } \\
\text { have complied with the SDDS program in year } t \text {. }\end{array}$ \\
\hline UNGA voting Alignment & $\begin{array}{l}\text { Codes votes in agreement with the US as } 1 \text {, in disagreement as } 3 \text {, and } 2 \text { for } \\
\text { abstentions. The resulting numbers are divided by total number of votes in the } \\
\text { UNGA, resulting in a measure coded between } 0 \text { and } 1 \text {, sourced from Strezhnev } \\
\text { and Voeten }(2012)\end{array}$ \\
\hline Economic Policy Reforms & $\begin{array}{l}\text { Coded on the scale of } 0-100 \text { where higher value means full economic freedom. } \\
\text { The index is made up of } 10 \text { sub-indices sourced from Heritage foundation }\end{array}$ \\
\hline General Transparency & $\begin{array}{l}\text { Coded between } 0-10 \text { where highest value represents transparency in policies } \\
\text { and institutions. The index is weighted average based on corruption ( } 20 \%) \text {; rule } \\
\text { of law (20\%); bureaucratic quality ( } 20 \% \text { ) and property rights ( } 40 \%) \text { sourced } \\
\text { from International Country Risk Guide (ICRG) }\end{array}$ \\
\hline
\end{tabular}

